\title{
Toward Scaling-Up Photocatalytic Process for Multiphase Environmental Applications
}

\author{
Mohamed Gar Alalm ${ }^{1,2}$, Ridha Djellabi ${ }^{3, *}$, , Daniela Meroni ${ }^{3}\left(\mathbb{D}\right.$, Carlo Pirola $^{3}\left(\mathbb{C}\right.$, Claudia Letizia Bianchi $^{3} \mathbb{C}$ \\ and Daria Camilla Boffito ${ }^{1, *(\mathbb{D})}$ \\ 1 Department of Chemical Engineering, Polytechnic Montreal, Montreal, QC H3C 3A7, Canada; \\ mgaralalm@polymtl.ca \\ 2 Department of Public Works Engineering, Faculty of Engineering, Mansoura University, \\ 35516 Mansoura, Egypt \\ 3 Department of Chemistry, University of Milano, Via Golgi 19, 20133 Milan, Italy; \\ daniela.meroni@unimi.it (D.M.); carlo.pirola@unimi.it (C.P.); claudia.bianchi@unimi.it (C.L.B.) \\ * Correspondence: ridha.djellabi@yahoo.com (R.D.); daria-camilla.boffito@polymtl.ca (D.C.B.)
}

Citation: Alalm, M.G.; Djellabi, R.; Meroni, D.; Pirola, C.; Bianchi, C.L.; Boffito, D.C. Toward Scaling-Up Photocatalytic Process for Multiphase Environmental Applications. Catalysts 2021, 11, 562. https:// doi.org/10.3390/catal11050562

Academic Editor: Fernando J. Beltrán Novillo

Received: 8 April 2021

Accepted: 26 April 2021

Published: 28 April 2021

Publisher's Note: MDPI stays neutral with regard to jurisdictional claims in published maps and institutional affiliations.

Copyright: (c) 2021 by the authors. Licensee MDPI, Basel, Switzerland. This article is an open access article distributed under the terms and conditions of the Creative Commons Attribution (CC BY) license (https:/ / creativecommons.org/licenses/by/ $4.0 /)$.

\begin{abstract}
Recently, we have witnessed a booming development of composites and multi-dopant metal oxides to be employed as novel photocatalysts. Yet the practical application of photocatalysis for environmental purposes is still elusive. Concerns about the unknown fate and toxicity of nanoparticles, unsatisfactory performance in real conditions, mass transfer limitations and durability issues have so far discouraged investments in full-scale applications of photocatalysis. Herein, we provide a critical overview of the main challenges that are limiting large-scale application of photocatalysis in air and water/wastewater purification. We then discuss the main approaches reported in the literature to tackle these shortcomings, such as the design of photocatalytic reactors that retain the photocatalyst, the study of degradation of micropollutants in different water matrices, and the development of gas-phase reactors with optimized contact time and irradiation. Furthermore, we provide a critical analysis of research-practice gaps such as treatment of real water and air samples, degradation of pollutants with actual environmental concentrations, photocatalyst deactivation, and cost and environmental life-cycle assessment.
\end{abstract}

Keywords: air pollution; photocatalysis; reactors; wastewater; water matrix; scaling up

\section{Introduction}

Air and water pollution represent serious concerns for human health and the livelihood of entire ecosystems. A vast range of priority pollutants (the most important regulated pollutants) and pollutants of emerging concerns (pollutants with severe health and environmental concerns but not yet regulated) can be found in industrial wastewaters and exhausts, or are released to the environment during the end-use of chemical products [1-3]. Air pollution, both outdoor and indoor, represents a major threat to human health, killing an estimated seven million people worldwide in 2016 [4], due to pollutants such as particulate matter, polyaromatic hydrocarbons, carbon monoxide, nitrogen oxides, and volatile organic compounds (VOCs). Widespread water pollutants include perfluoroalkyl substances (PFASs), pharmaceuticals and personal care products (PPCPs), pesticides, and endocrine-disrupting compounds (EDCs) [5].

Although most of these pollutants are present in the aquatic environment in very low concentrations (usually in the range of $\mu \mathrm{g} \cdot \mathrm{L}^{-1}$ and $\mathrm{ng} \cdot \mathrm{L}^{-1}$ ), they have severe direct and indirect repercussions on the environment and human health [6]. For instance, very low concentrations of antibiotics may favor the development of antibiotic resistance in certain microorganisms [7].

Conventional pollutant removal technologies present numerous shortcomings. For instance, conventional biological wastewater treatment methods are able to break $\mathrm{C}-\mathrm{C}$ 
bonds in organic pollutants, but they have limited ability to destroy other strong bonds in complex micropollutants, especially when easily digestible organics exist as a favored food for microorganisms, such as in domestic wastewater [6]. Advanced oxidation processes (AOPs) have been recognized to be efficient for the degradation of persistent organic molecules through the generation of strong reactive oxygen species (ROS). Among AOPs, photocatalysis is distinguished by its ability to generate diverse ROS, its durability, and its oxidation efficacy toward numerous families of micropollutants [8-10].

Notwithstanding the myriad studies reporting the degradation of diverse air and water pollutants by state-of-the-art photocatalysts, there is increasing skepticism about the full-scale application of photocatalysis for environmental purposes [11-13]. Obviously, the recent research in photocatalysis has been largely inspired by advances in materials science, nanotechnology, and characterization techniques [14]. The fascinating properties of novel nanomaterials such as quantum dots, metal-organic frameworks (MOFs), graphene, doped metal oxides, and their composites have attracted many researchers to explore their photocatalytic activity at the expense of engineering aspects [15-17]. Consequently, the literature of photocatalysis research is overstuffed with novel nanocomposites and their advanced characterizations to prove the successful synthesis and unique properties. Photocatalytic experiments were often conducted by the dispersion of a photocatalyst in a single-pollutant solution under well-controlled conditions [11]. In contrast, fewer studies focused on designing photocatalytic reactors or simulating real water/wastewater streams $[18,19]$.

The benchmark photocatalyst, $\mathrm{TiO}_{2}$, is distinguished by high thermal, chemical and photochemical stability, and low cost, but it lacks the sensitivity to visible light and is only activated under UV light [11,20], it presents low quantum yields [11] and its health effects have recently come under increased scrutiny [21]. Novel visible light photocatalysts promise to overcome the limitations of $\mathrm{TiO}_{2}$ in terms of activity range, but generally there is a lack of knowledge about their cost and toxicity.

The photocatalyst particles are not consumed during the illumination, and hence they can be reused for several cycles until the active surface is blocked by the accumulation of organic matter [22]. The active sites can be maintained by prior biological treatment, which also provides a clearer medium and reduces the competition on the ROS [23]. However, the collection of the dispersed particles is a tedious process and may require prior magnetization [24]. To overcome these shortcomings, some attempts have been made to design photocatalytic reactors with retained catalysts, but the full-scale potential of these approaches remains elusive [14,25-28].

The presence of multiple pollutants, electrolytes and other dissolved species in real water matrices is known to affect, often negatively, the photocatalytic performance [29]. Yet comparatively few studies have reported the degradation of micropollutants in different water matrices to simulate real water/wastewater streams [30,31].

The application of photocatalysis for the removal of air pollutants suffers instead from mass transfer issues, which limit the process efficiency and can instead give rise to accumulation of undesired by-products due to sub-optimal contact times between the pollutant and the active surface [29].

Photocatalysis toward air purification faces some technological issues as well as depends on the specific application (purification of industrial polluted air, photoconversion of toxic gas into valuable products, self-cleaning systems, photocatalytic filters, etc.) [32]. For example, since photocatalysis suffers from poor mass transfer, engineering photoactive materials with unique properties and building special photoreactors may resolve/reduce this problem.

Overall, several research-practice gaps need to be tackled to encourage investments in photocatalytic technology. This report provides a critical overview of the knowledge gaps that hinder the full-scale application of photocatalysis in air and water/wastewater purifications, such as reactor design and scale-up, cost estimation, indirect implications for the environment, photocatalyst lifetime, and treatment efficiency in the case of low pollu- 
tant concentrations and real water/wastewater matrices. Finally, we offer a perspective on some of the most promising recent attempts for addressing these crucial issues.

\section{Photocatalysis for Water Purification}

\subsection{Reactor Design}

The basic function of photocatalytic reactors is providing contact between the illuminated catalyst and pollutants. This can be easily and efficiently attained by dispersing the photocatalyst particles in a vigorously stirred vessel under an appropriate irradiation source. This simple approach has in fact been employed in the majority of studies reporting the photocatalytic degradation of micropollutants or disinfection [33-36]. Notwithstanding the high photon absorption and efficient ROS interaction with pollutants in the case of dispersed catalysts, the photocatalyst reuse is hindered by the difficulty of recovering the nanostructured powder at the end of the process. To prove the stability and reusability of the dispersed photocatalysts, some researchers added drops of concentrated pollutants after the first photocatalytic cycle [7]; however, this approach is obviously not applicable in real life. Furthermore, the potential release of photocatalyst powder represents another major drawback of setups using dispersed catalysts, because the toxicity of the nanoparticles and their repercussions on the environment are not yet fully understood.

Reactors employing photocatalysts in retained forms can facilitate reusability, eliminating the need for powder recovery, which generally requires ultrafiltration and, at the same time, they reduce the risks associated with nanoparticle release to the environment. We advocate for this strategy as a practical translation of bench-scale studies to full-scale water/wastewater treatment.

The fluidized-bed photocatalytic reactor is an example of photocatalytic systems that keep the photocatalyst within its boundary. In this system, the water flow is circulated with a proper velocity to keep the fluidized photocatalyst in a certain position inside the reactor [12]. In this sense, the catalyst remains in the reactor, and thus there is no need for a collection step. However, the fluidized-bed system has rarely been used due to the low weight and high dispersibility of most photocatalysts [27]. Development of photocatalysts with bigger particle size to overcome the high dispersibility would be at the expense of the active surface area, leading to lower light absorption. To attain appropriate photocatalytic suspensions, anchoring the photocatalyst on a porous substrate can also provide the additional benefit of promoting pollutant adsorption. For instance, Fang et al. prepared a composite macrostructure of $\mathrm{TiO}_{2}$ nanotubes and graphene for the adsorption and degradation of bisphenol $\mathrm{A}$ in a fluidized-bed reactor [37]. This system, using a flow rate of $1 \mathrm{~mL} / \mathrm{min}$, showed $86 \%$ and $50 \%$ pollutant removals for, respectively, $0.05 \mathrm{mg} / \mathrm{L}$ and $0.5 \mathrm{mg} / \mathrm{L}$ bisphenol A solutions; the removal performance remained constant during 1000 min tests.

The light source in fluidized-bed photoreactors can be placed at the center of the reactor or at the reactor walls, adopting either tubular UV lamps or LED lights $[38,39]$ (Figure 1).

Alternatively, reactors using photocatalysts immobilized on a solid, fix support have been proposed as a solution allowing long operation periods with minimum catalyst loss [40]. Among them, reactors based on photocatalytic membranes have attracted increasing interest because immobilizing the photocatalysts at the membrane surface improves the mass transfer of pollutants to the photocatalytic sites [11]. The choice of the membrane materials is limited by the oxidative stress caused by the photocatalyst material: Suitable materials include polyethersulfone (PES) [41] or polyvinylidene fluoride (PVDF) membranes. Numerous types of photocatalyst immobilization procedures have been reported, such as dip coating [42], spray coating [43], layer-by-layer self-assembly [44] and blending with the polymer matrix [41]. Alternatively, porous photocatalyst morphologies can be used to obtain freestanding photocatalytic membranes [45,46]. During the operation of a photocatalytic membrane reactor, the contaminated water flows through the illuminated membranes for several cycles until the desired degradation is achieved, so the photocat- 
alyst is kept in the reactor without the need for collection (Figure 2). Consequently, flow rate represents a crucial parameter for the operation of the membrane reactor, as it affects mass transport of the reagents to the catalytic sites as well as contact time between the pollutant and the photocatalyst [47]. Liu et al. immobilized $\mathrm{ZnIn}_{2} \mathrm{~S}_{4}$ on a PVDF membrane by phase inversion method for the photocatalytic degradation of fluvastatin [48]. Almost complete degradation of $10 \mathrm{mg} / \mathrm{L}$ fluvastatin was attained in $180 \mathrm{~min}$ of irradiation and the reuse for six cycles retained about $91.5 \%$ of the initial efficiency. In another study, Wei et al. developed a reduced graphene oxide membrane loaded with graphitic carbon nitride $\left(\mathrm{g}-\mathrm{C}_{3} \mathrm{~N}_{4}\right)$ for the degradation of $5 \mathrm{mg} / \mathrm{L}$ rhodamine $\mathrm{B}$ under visible light [49]. The recycle reactor removed $98.7 \%$ of the dye in $90 \mathrm{~min}$ and a high permeability rate was retained for $300 \mathrm{~min}$, but reuse was not studied. Fischer et al. loaded $\mathrm{TiO}_{2}$ on a PES membrane by dip coating and ultrasound modifications [50]. Interestingly, the produced membrane achieved complete degradation of $13 \mathrm{mg} / \mathrm{L}$ methylene blue within $40 \mathrm{~min}$ for a consecutive nine cycles.
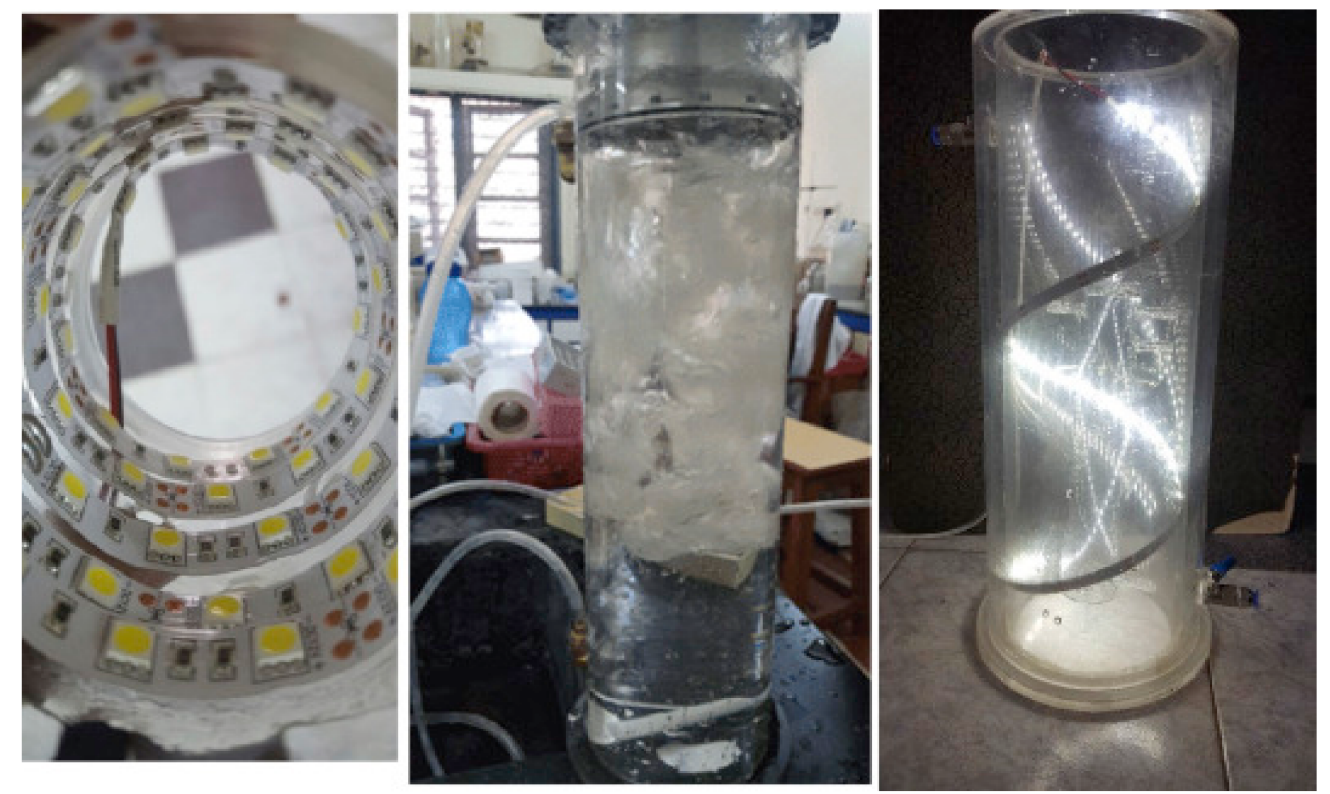

Figure 1. Fluidized-bed-type LED reactor with immobilized catalyst on polymer supports; reproduced with permission from [39], Copyright 2019, Elsevier.

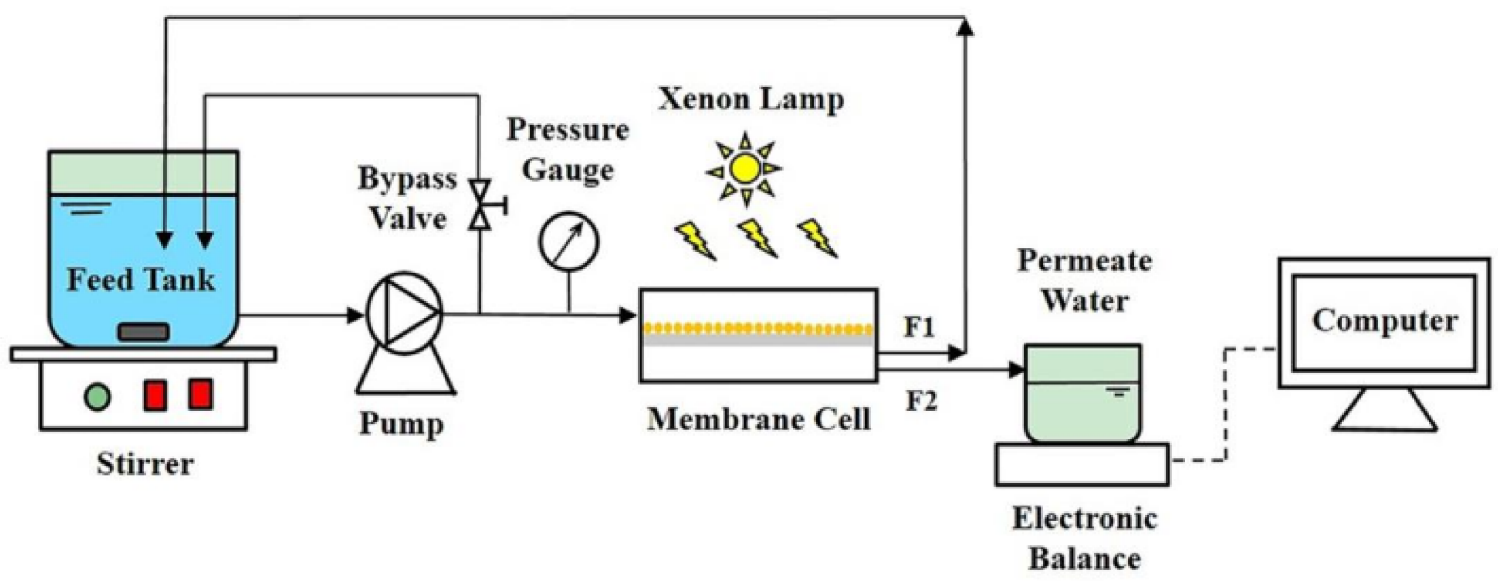

Figure 2. Photocatalytic membrane reactor operated in cross-flow filtration mode, where the feed solution is continuously recirculated tangentially to the membrane; reproduced with permission from [48], Copyright 2020, Elsevier. 
Other reactor configurations involving an immobilized, fixed photocatalyst rely on the coating of internal reactor surfaces with the photocatalyst. Some examples of this strategy are reported in Figure 3. For instance, Behnajady et al. [51] reported a reactor design based on $\mathrm{TiO}_{2}$-coated longitudinal glass plates $(15 \times 290 \mathrm{~mm})$ illuminated by $30 \mathrm{~W}$ UV-C lamps (Figure $3 \mathrm{a})$. The reactor was operated in a continuous-flow mode under different volumetric flow rates, and it completely degraded $30 \mathrm{mg} / \mathrm{L}$ Acid Red 27 at a flow rate of $15 \mathrm{~mL} \cdot \mathrm{min}^{-1}$. However, this type of reactor design is prone to photocatalyst deactivation due to the limited irradiated surface area [47]. In this respect, immobilization of the photocatalyst on substrates such as Rashig rings [52] can promote the overall photocatalyst surface area and mass transfer due to turbulent flow conditions within the reactor. Other concerns regard filming problems at the glazing/lamp surface due to accumulation of dirt from wastewater, and the need for air or oxygen purging to maintain aeration in the closed reactor.

Another alternative is represented by thin film fixed-bed reactors, which are falling film recycle reactors using an immobilized photocatalyst. In these reactors, water flows in a laminar flow over an inclined flat plate coated with the photocatalyst, and it is recirculated in a batch mode. This kind of setup does not require air/oxygen purging to maintain aerated conditions and can work using non-concentrated solar radiation [53]. For instance, Fouad et al. reported the use of $\mathrm{W}-\mathrm{TiO}_{2}$ coating on inclined stainless steel plates illuminated by two metal halide lamps placed above the reactor (Figure 3d) [54]. By this configuration, complete degradation of $30 \mathrm{mg} / \mathrm{L}$ sulfamethazine was attained in $120 \mathrm{~min}$, and the reuse for five consecutive cycles showed that the catalyst could retain $90 \%$ of its initial performance. A similar geometry was used for the disinfection of real surface waters collected from the intakes of water treatment plants by $\mathrm{Ru}-\mathrm{WO}_{3} / \mathrm{ZrO}_{2}$ using visible light [55]. The photocatalytic system disinfected different water samples of 300 to $5000 \mathrm{CFU} \cdot \mathrm{mL}^{-1}$ (CFU: colony-forming units) that included Gram negative and Gram positive bacteria, and the coated plates kept their activity after four cycles of consecutive reuse. This reactor type was further developed by Samy et al. to include an additional vertical plate with a chamber illuminated from a lateral borosilicate glass side (Figure 3e) [56,57].

(a)

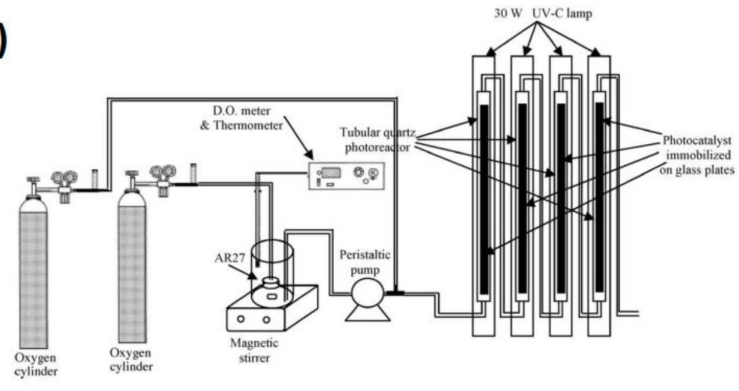

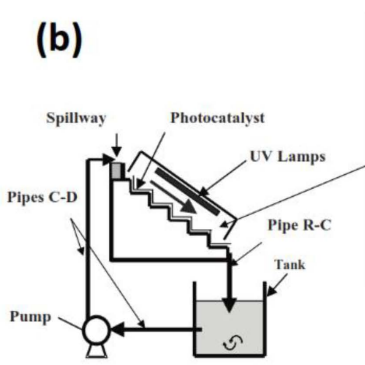

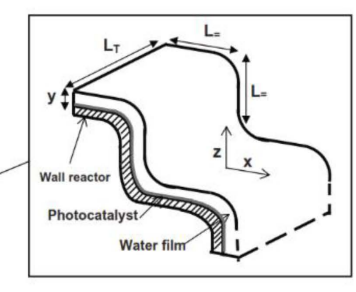

(e)

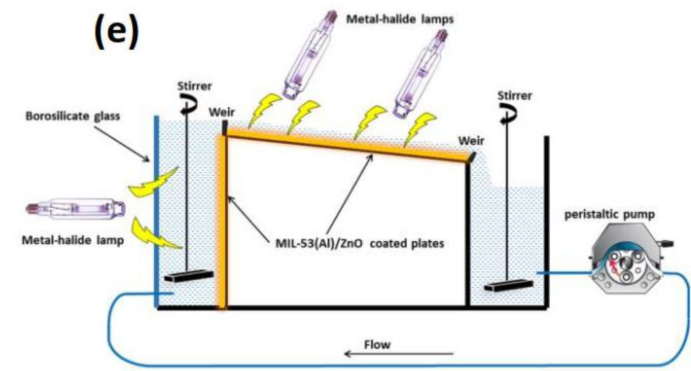

\section{(c)}

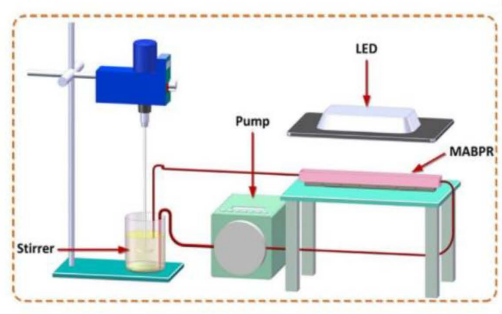

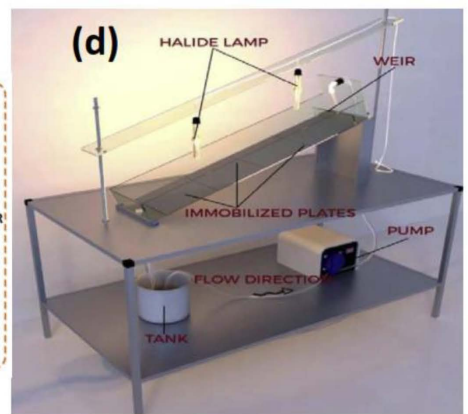

Figure 3. (a) Schematic diagram of a tubular continuous reactor with immobilized photocatalyst; (b) Thin film cascade photoreactor; (c) Magnetic bed reactor; (d-e) Examples of thin film fixed-bed reactors; reprinted with permission from [51] (a), [58] (b), [59] (c), [54] (d), [56] (e). 
However, laminar flow adopted in thin film fixed-bed reactors limits mass transfer, resulting in a slow treatment kinetics, hence large areas are required to attain an acceptable degradation efficiency. To solve this problem, thin film cascade photoreactors have been proposed. This setup uses turbulence introduced by waterfall to promote mass transfer (Figure 3b). For instance, Stephan et al. developed a falling film recycle reactor comprised of fiber steps coated by $\mathrm{TiO}_{2}$, whereby the contaminated water flowed in a closed loop [58]. The reactor degraded $5 \mathrm{mg} / \mathrm{L}$ chlortoluron in less than $160 \mathrm{~min}$, but reusability was not investigated. In this respect, thin film and cascade photoreactors require the development of affordable techniques for a highly stable immobilization of the photocatalyst on large flat surfaces.

In this respect, Sun et al. recently reported an interesting alternative, based on a magnetic bed photocatalytic recycle reactor. In this study, magnetic photocatalyst particles of $\mathrm{CoFe}_{2} \mathrm{O}_{4}-\mathrm{Ag}_{2} \mathrm{O}$ were anchored by an external magnet to the bottom of the reactor (Figure 3c) [59]. The magnetization of $\mathrm{Ag}_{2} \mathrm{O}$ by $\mathrm{CoFe}_{2} \mathrm{O}_{4}$ was not only beneficial for holding the photocatalyst, but it also reduced the band gap so that the composite could be activated by visible light. This system degraded $92 \%$ of methyl orange in $60 \mathrm{~min}$, but the degradation was reduced to $80 \%$ after three cycles of reuse. Despite the fact that the efficiency of this reactor is lower than those of many other photocatalytic systems in the literature, it is a very novel and promising system that could be developed on larger scales. Table 1 lists some recent examples of reactors with retained photocatalysts and their application for the removal of water pollutants.

Despite the large amount of literature on the topic, there are still several issues that hinder the full-scale application of reactors with retained photocatalyst. First, reported processing capacities are generally limited, owing to mass transfer limitations and the inherent kinetics of the photocatalytic process. In order to promote degradation efficiency, higher residence times are needed, which, however, limits process throughput. Few investigations have reported on pilot-scale reactors [53,60], and most of these studies have employed slurry-based photoreactors [61-63]. Moreover, numerous studies on reactor configurations focus merely on the main pollutant disappearance without providing information on the reaction intermediates, which oftentimes are still toxic and poorly biodegradable compounds [64]. The evaluation of the long-term performance of the photocatalytic systems is also another scantly investigated point, as most studies report, at best, a few photocatalytic consecutive tests. In this respect, decreasing performance in consecutive tests is often indicative of photocatalyst leaching due to mechanical and thermal stress or to accumulation of pollutants and their transformation products on the active sites, which can translate into unsatisfactory system lifetime. 
Table 1. Different reactors employing the photocatalysts in retained forms.

\begin{tabular}{|c|c|c|c|c|c|c|c|c|}
\hline Reactor Type & Photocatalyst & Pollutant & Irradiation Source & $\begin{array}{c}\text { Max } \\
\text { Degradation \% }\end{array}$ & $\begin{array}{l}\text { Reaction Time } \\
\text { (min) }\end{array}$ & $\begin{array}{l}\text { No of Reuse } \\
\text { Cycles }\end{array}$ & $\begin{array}{c}\text { Degradation \% } \\
\text { at Last Cycle }\end{array}$ & Reference \\
\hline Fluidized bed reactor & $\begin{array}{c}\mathrm{TiO}_{2} \text { nan- } \\
\text { otubes/graphene }\end{array}$ & Bisphenol A & 350W Xe lamp & $100 \%$ * & 30 & 5 & $92 \%$ & [37] \\
\hline Photocatalytic PVDF membrane & $\mathrm{ZnIn}_{2} \mathrm{~S}_{4}$ & Fluvastatin & $500 \mathrm{~W}$ Xe lamp & $99.75 \%$ & 180 & 6 & $91.53 \%$ & [48] \\
\hline Photocatalytic graphene oxide membrane & $\mathrm{g}-\mathrm{C}_{3} \mathrm{~N}_{4}$ & Rhodamine B & $\begin{array}{l}300 \text { W Xe lamp with } 420 \\
\text { nm cut-off filter }\end{array}$ & $98.7 \%$ & 90 & - & - & [49] \\
\hline Solar membrane reactor & $\mathrm{TiO}_{2}$ & Tartrazine & Natural solar light & $78 \%$ & 300 & 2 & $67 \%$ & {$[65]$} \\
\hline Photocatalytic polymer membrane & $\mathrm{TiO}_{2}$ & Methylene blue & Solar lamp & $100 \%$ * & 40 & 9 & $100 \%$ * & {$[50]$} \\
\hline Coated plate reactor & $\mathrm{W}-\mathrm{TiO}_{2}$ & Sulfamethazine & $400 \mathrm{~W}$ metal-halide lamp & $100 \% *$ & 120 & 5 & $90.3 \%$ & [54] \\
\hline Tubular continuous-flow with attached catalyst & $\mathrm{TiO}_{2}$ & Acid Red 27 & 30 W UV-C lamps & $100 \%$ * & - & - & - & [51] \\
\hline Falling film reactor & $\mathrm{TiO}_{2}$ & Chlortoluron & 24 W UV lamp & $100 \%$ * & 250 & - & - & [58] \\
\hline Submerged coated plate & $\mathrm{Ru}-\mathrm{WO}_{3} / \mathrm{ZrO}_{2}$ & Multiple bacteria & $400 \mathrm{~W}$ metal-halide lamp & $100 \%$ * & 240 & 4 & $100 \%$ * & [55] \\
\hline Submerged coated plate & $\mathrm{S}-\mathrm{TiO}_{2}$ & 2,4-dichlorophenol & $400 \mathrm{~W}$ metal-halide lamp & $98 \%$ & 480 & 5 & $80 \%$ & [66] \\
\hline Coated plate reactor & $\begin{array}{l}\mathrm{ZrV}_{2} \mathrm{O}_{7} / \text { graphene } \\
\text { nano-platelets }\end{array}$ & Chlorpyrifos & $400 \mathrm{~W}$ metal-halide lamp & $96.8 \%$ & 90 & 5 & $91 \%$ & [57] \\
\hline Magnetic aggregation bed reactor & $\mathrm{CoFe}_{2} \mathrm{O}_{4}-\mathrm{Ag}_{2} \mathrm{O}$ & Methyl orange & $600 \mathrm{~W}$ LED lamp & $92 \%$ & 60 & 3 & $80 \%$ & [59] \\
\hline Submerged coated plate & $\mathrm{Fe}-\mathrm{Cr}-\mathrm{N}-\mathrm{TiO}_{2}$ & Direct blue 15 & 20 W LED lamp & $100 \%$ * & 60 & - & - & [67] \\
\hline Submerged membrane reactor & $\mathrm{Fe}-\mathrm{ZnS} / \mathrm{g}-\mathrm{C}_{3} \mathrm{~N}_{4}$ & p-nitro-phenol & $500 \mathrm{~W}$ Xe lamp & $93.5 \%$ & 300 & - & - & [19] \\
\hline Micro-meso-reactor & $\mathrm{TiO}_{2}$ & $\mathrm{Cr}(\mathrm{VI})$ & 1700 W Xe lamp & $100 \%$ * & 60 & 10 & $70 \%$ & [68] \\
\hline
\end{tabular}

* $100 \%$ means that the residual concentration was below the detection limit of the analytical method. 


\subsection{Photocatalytic Activity in Complex Water Matrices and Real Samples}

In addition to considerations related to reactor design, other challenges regard the role of the water matrix. Most studies have reported photocatalytic experiments in ideal lab conditions such as pure water solutions of a single pollutant at an easily quantifiable concentration (from few $\mathrm{mg} \cdot \mathrm{L}^{-1}$ to even max solubility) [69]. While rigorously controlled conditions are adopted for the sake of the characterization of novel photocatalysts, they are far from the real scenario. In fact, real industrial wastewater streams always contain a mix of pollutants in complex matrices, which include numerous electrolytes and natural organic matter (NOM). Moreover, the concentrations of micropollutants in drinking and surface water are generally in the range of $\mathrm{ng} \cdot \mathrm{L}^{-1}$ to $\mu \mathrm{g} \cdot \mathrm{L}^{-1}$, hence far lower than in most of the literature studies about photocatalytic remediation.

\subsubsection{Presence of Interfering Species and Real Water Matrices}

Most literature studies have adopted photocatalytic tests involving a single pollutant at the time in a synthetic water matrix to avoid interfering effects, particularly from unknown organic species. The photocatalytic degradation of pollutants in background-free and transparent water is ideal for lab studies to investigate the interaction between the catalyst and pollutant and the contribution of different ROS in the oxidation. However, this is not the case in real practice, such as in the treatment of surface water, industrial wastewater, or groundwater, where a wide variety of substances can be found [70]. The occurrence of organic or inorganic species other than the main pollutant may inhibit the photocatalytic degradation or require additional amounts of catalyst [71]. Moreover, photocatalysts can exhibit largely different responses to complex water matrices [64], which underscores the limited value of comparisons of photocatalytic activity in ultra-pure water.

Some inorganic electrolytes, such as bicarbonates and chlorides, can have a detrimental effect on the photocatalytic activity by acting as radical scavengers [29]. However, the overall effect depends on the pollutant and on the relative concentration of the species.

Repousi et al. investigated the photocatalytic degradation of bisphenol A by $\mathrm{Rh}-\mathrm{TiO}_{2}$ in ultra-pure water, humic acid solution, solution of inorganic salts found in bottled water, and secondary treated wastewater [72]. The presence of humic acid enhanced the degradation of bisphenol A in this study, which was imputed to the reduced aggregation of $\mathrm{Rh}-\mathrm{TiO}_{2}$ particles by the repulsion forces induced by the accumulation of humic acid on their surface. On the other hand, the degradation was 30 times slower in the treated wastewater matrix despite the whole organic content (Total organic carbon $(\mathrm{TOC})=6.2 \mathrm{mg} \cdot \mathrm{L}^{-1}$ ) being much lower than the humic acid organic content $\left(\mathrm{TOC}=9.2 \mathrm{mg} \cdot \mathrm{L}^{-1}\right)$. Although the organic content of treated wastewater was unknown, it was expected to contain persistent organics that survived during the biological treatment and could scavenge the ROS during the photocatalytic reaction.

Awfa et al. examined the degradation of carbamazepine by a composite of carbon nanotubes (CNTs) and $\mathrm{TiO}_{2}$ in two stages of treated domestic wastewater, river water, and three commercial synthetic natural organic matter (NOM) solutions, viz, Suwannee River humic acid (SRHA), Suwannee River reverse-osmosis isolates (SRNOM), and Suwannee River fulvic acid (SRFA) [30]. The degradation of carbamazepine was reduced from 93\% in ultra-pure water to $87 \%$ and $40 \%$ in river water and treated wastewater, respectively. Furthermore, inhibition by commercial NOM surrogates was in the order of SRHA, SRFA, SRNOM, indicating that the inhibitory effect depends on the characteristics of NOM such as aromaticity (ratio of aromatic content to total organic content), molecular weight, and light absorption. In another study, Ren et al. investigated the inhibitory effects of lake water and a synthetic solution of alginic acid sodium and citric acid on the degradation of clofibric acid [70]. The results revealed that the inhibition of photocatalytic activity was influenced by the molecular weight of NOM more than its concentration. It was also noted that increasing the dissolved oxygen could decrease the inhibitory effect due to the enhanced production of superoxide radicals, whereas changing the $\mathrm{pH}$ did not affect the degradation rates. 
NOM can inhibit the photocatalytic degradation of micropollutants by different concurrent mechanisms according to the nature and concentration of existing organic substances. Firstly, the photocatalytic activity can be reduced by the inner filter effect, i.e., a lower effective irradiation of the photocatalyst due to light absorption by organic compounds [30]. This effect is greatly dependent on the molecular structure of NOM, as complex organic structures absorb light on a broader range than simple organics and secondary by-products [73]. Specific UV absorbance (SUVA), which is the ratio of UV absorbance at $254 \mathrm{~nm}\left(\mathrm{UV}_{254}\right)$ to dissolved organic carbon (DOC), describes aromaticity of NOM based on the light absorption at $254 \mathrm{~nm}$ of the benzene rings. Higher SUVA values refer to the existence of higher content in aromatic organics regardless of the NOM concentrations [74]. Accordingly, water matrices with higher SUVA are expected to require higher light intensity to activate the surface of the photocatalyst as a compensation for what will be absorbed by NOM.

The photocatalytic activity can be also inhibited by the accumulation of NOM on the surface of photocatalyst particles, which blocks the active sites and reduces the illuminated area [55]. This accumulation decreases the production of ROS even if the catalyst is well illuminated. NOM with high aromatic content is more likely to be hydrophobic, and hence it is more adsorbed at the photocatalyst surface [75]. Furthermore, aromatic NOM quenches the holes in the valence band of the photocatalyst, which not only reduces the degradation caused by the holes but also inhibits the production of hydroxyl radicals [76]. NOM and its transformation products further scavenge the generated ROS in the polluted water, inhibiting the oxidation of the target pollutants.

Although several studies investigated the influence of NOM on the photocatalytic degradation of micropollutants, the effect of the photocatalytic process on the NOM composition still needs to be clarified. This may be attributed to the challenges associated with the characterization of molecular structure variations of NOM, which limits many studies to aromaticity, fluorescence, etc. [77]. This research gap can be filled by advanced analytical techniques based on high-resolution mass spectrometry (MS), such as Fourier transform ion cyclotron resonance (FT-ICR-MS), Orbitrap MS, and time-of-flight MS. Such techniques could identify the dominance of certain organic compounds based on their molecular weights, which can shed light on the changes in the dissolved organic matter during the photocatalysis.

\subsubsection{Degradation of Pollutants at Low Concentration}

Investigating the removal of micropollutants in the range of $\mathrm{ng} \cdot \mathrm{L}^{-1}$ to $\mu \mathrm{g} \cdot \mathrm{L}^{-1}$ to simulate natural water streams and groundwater is hindered by the accuracy and detection limit of the analytical methods. In the case of target analysis, photometric and chromatographic methods are often used to evaluate the photocatalytic degradation. In most cases, these methods are appropriate for the $\mathrm{mg} \cdot \mathrm{L}^{-1}$ scale because neither the accuracy nor the detection limit is adequate to work under $0.1 \mathrm{mg} \cdot \mathrm{L}^{-1}$.

The environmental concentrations of emerging micropollutants usually fall below this range and also in the case of several priority pollutants, threshold limits are becoming more and more rigorous. For instance, the maximum allowed concentration of pesticides in drinking water in the European Union is $0.1 \mu \mathrm{g} \cdot \mathrm{L}^{-1}$, while the maximum annual average concentration of perfluorosulfonic acid and its derivatives is $0.65 \mathrm{ng} \cdot \mathrm{L}^{-1}$ [78].

Recently, gas or liquid chromatography coupled with tandem mass spectrometry (MS/MS) allowed the analysis of micropollutants with an accuracy of a few $\mathrm{ng} \cdot \mathrm{L}^{-1}$ and the identification of transformation products by suspect screening [2]. However, these technologies are not widely available due to their high cost. Researchers who have no continuous access to these technologies tend to choose model pollutants with high concentrations to get clear peaks in conventional liquid or gas chromatography.

Considering that water streams usually contain thousands of listed organic substances, it is impractical to use target analysis to confirm the suitability of water for certain purposes [78]. This issue may be solved by nontarget analysis, whereby thousands of 
organic compounds can be detected with relative dominancy without the need for reference standards [79]. For instance, high-resolution mass spectrometry (MS) can detect the mass-to-charge ratios $(\mathrm{m} / \mathrm{z})$ with a precision of $10^{-5} \mathrm{Da}$, allowing accurate identifications of organic compounds by computer-assisted data-processing tools [2]. With the spreading of these technologies, we expect to witness photocatalysis studies aiming at investigating the treatment of real water/wastewater based on non-target analysis and very low concentrations in the near future.

Another approach evaluated the photocatalytic degradation by the removal of dissolved organic carbon (DOC), chemical oxygen demand (COD), or detoxification. For instance, Arcanjo et al. used $\mathrm{TiO}_{2}$ modified by iron oxide and hydrotalcite for the treatment of a textile industry wastewater [80]. Although the color removal reached $96 \%$, the COD and DOC removals were not as high (less than $20 \%$ and $10 \%$ for the COD and DOC in $360 \mathrm{~min}$, respectively). The modest removal was imputed to the formation of recalcitrant by-products that may require a longer time for degradation. The toxicity was assessed by the 48-h immobilization test of Daphnia similes regarding $\mathrm{EC}_{50}$ (dilution causing $50 \%$ immobility) showing a decrease of toxicity (from $\mathrm{EC}_{50}=70 \%$ to $\mathrm{EC}_{50}=95 \%$ by pristine $\mathrm{TiO}_{2}$ and to $\mathrm{EC}_{50}=79 \%$ by modified $\mathrm{TiO}_{2}$ ). Comparable examples of real industrial and municipal wastewaters detoxified by photocatalysis were recently reviewed elsewhere [3,81]. In a different application, Fouad et al. studied the disinfection of real surface waters collected from the intakes of water treatment plants in the Nile Delta using $\mathrm{Ru}-\mathrm{WO}_{3} / \mathrm{ZrO}_{2}$ [55].

\subsection{Cost and Environmental Life-Cycle Assessment}

Many researchers claim they have developed the state-of-the-art photocatalyst but provide no information about its cost, toxicity, or life cycle [11]. These issues are of crucial importance in terms of the actual full-scale applicability of any photocatalytic technology.

The economic sustainability of photocatalytic wastewater treatment on a large scale is generally discussed in terms of electrical energy per order $\left(\mathrm{E}_{\mathrm{EO}}\right)$ values $[82,83]$. While several advance oxidation processes, including ozonation, $\mathrm{UV} / \mathrm{H}_{2} \mathrm{O}_{2}, \mathrm{UV} /$ persulfate, and $\mathrm{UV} /$ chlorine, present median $\mathrm{E}_{\mathrm{EO}}$ values $<1 \mathrm{kWh} / \mathrm{m}^{3}$, hence, are considered competitive for drinking water applications, the $\mathrm{E}_{\mathrm{EO}}$ values for photocatalysis with $\mathrm{UV}$ activation are generally $>10-100 \mathrm{kWh} / \mathrm{m}^{3}[84,85]$. To make photocatalytic water remediation a competitive approach for municipal wastewater treatment, this value needs to be reduced.

Although evaluating the energy efficiency of the process via $\mathrm{E}_{\mathrm{EO}}$ is encouraged, comparisons among different technologies using this single parameter can be misleading. Other factors should be considered, such as the embedded energy costs of consumable chemicals [11]. In this respect, life-cycle assessment (LCA) provides a more complete picture of the overall sustainability of a remediation process. LCA is an integrated procedure to compile the environmental impacts associated with a process due to the materials, energy consumption, and emissions from cradle-to-grave, based on a huge number of databases [86]. Despite the wealth of literature dedicated to new photocatalysts, the environmental impacts associated with the production and operation of these catalysts are usually ignored. Only a few studies have compared the impacts of photocatalysis by $\mathrm{TiO}_{2}$ for the removal of micropollutants with other treatment processes. Magdy et al. found that photocatalytic degradation of phenol by $\mathrm{TiO}_{2}$ in a compound parabolic collectors (CPCs) reactor was more eco-friendly than electro-Fenton and activated carbon adsorption processes, whereas the photo-Fenton process in the same CPCs reactor had less environmental impact [87]. The main contributors to the environmental impact were the production of $\mathrm{TiO}_{2}$, electricity used for circulating the water in the reactor, and residual transformation products in the same order. Muñoz et al., when comparing solar Fenton and solar-based heterogenous photocatalysis, reported a similar conclusion [88]. On the contrary, Pesqueira et al. found that the photo-Fenton process had a higher environmental impact than $\mathrm{TiO}_{2}$ photocatalysis for degradation of a group of pharmaceuticals [89]. This dissimilarity may be attributed to the difference in the chemical dosages and reaction times. It should be noted that LCA analyses of photocatalytic processes have been scarcely reported in the 
literature. A complete LCA analysis is indeed very challenging because most new complex photocatalysts are not included in LCA databases yet, so researchers have to build the LCA inventory to include the precursors and energy consumption of the catalyst synthesis. Moreover, notable gaps still exist in our knowledge, particularly concerning the toxicity and environmental impact of novel nanostructures.

The cost estimation of photocatalytic water/wastewater treatment on a large scale has been hindered by the lack of information about the commercial prices of novel catalysts. In fact, most of the recent composites used for enhancing the photocatalysis under visible light are not produced in commercial scales. Furthermore, the required amounts for the treatment of industrial wastewaters are elusive to identify due to the rarity of studies on real wastewater, as discussed in the previous section. Therefore, only a few studies have estimated the costs of wastewater treatment by photocatalysis $[14,90,91]$. However, these few studies were for specific cases regarding the pollutants and photocatalysts, and hence they could not present substantial generic costs.

\section{Photocatalysis for Air Purification}

For more than three decades, the scientific community has devoted a great deal of effort to developing photocatalytic processes for the removal of a range of air pollutants [92-97]. Photocatalysis was demonstrated to be effective for the removal of pollutants in gas phase at relatively low concentrations [98]. Different photocatalytic materials and photoreactors have been proposed [94,98-100]. However, similar to the case of photocatalytic water treatment [10], the process scale-up for the photocatalytic air purification is still an open challenge [101].

When it comes to the application of photocatalysis in a real air system, different approaches can be envisaged:

(i) Photocatalytic self-cleaning and antimicrobial materials to be used in indoor/outdoor areas: Under natural solar light (outdoor) or LED irradiation (indoor), the photoactive self-cleaning materials can initiate photocatalytic reactions able to clean continuously their surface and/or treat air pollutants [102-104]. This system is very promising and has received a lot attention from the industrial community [105-107]. Numerous types of self-cleaning coatings and building materials have been developed and commercialized for both indoor and outdoor applications. For instance, Bianchi et al. [107-109] reported a novel digital printing technology for the coating of tiles by visible light-responsive Ag nanoparticle-decorated $\mathrm{TiO}_{2}$ (Figure 4). This scalable technology allows obtaining a homogenous coating without the loss of photoactivity.

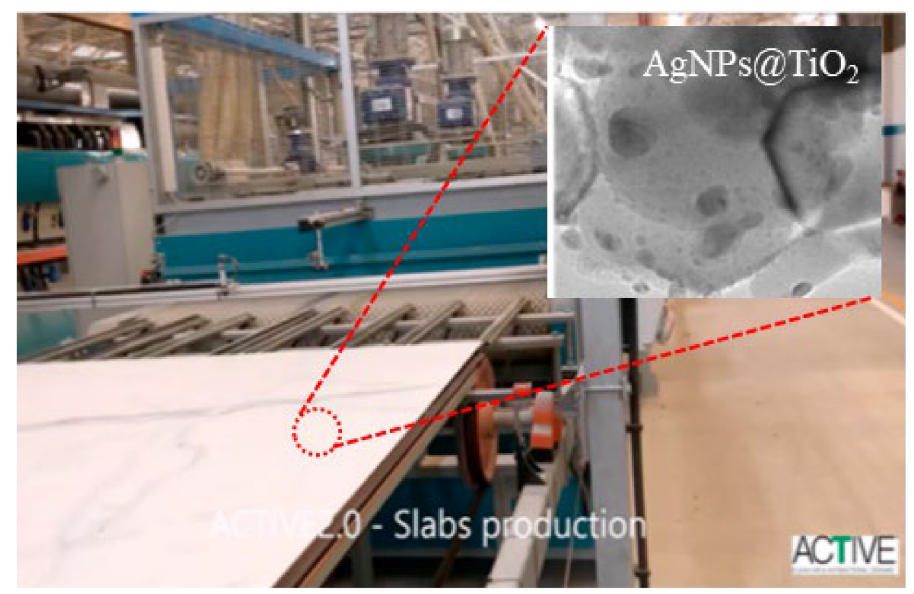

Figure 4. Photocatalytic self-cleaning industrial ceramics based on Ag nanoparticle-decorated TiO2 (inset) (by IrisCeramica Group-Italy) for the purification of contaminated air and bacteria inactivation, reproduced with permission from reference [109]. 
(ii) Photocatalytic purification of contaminated air in indoor, small spaces, such as aircraft cabins [32] and cold rooms [110]: while some air purifier devices based on photocatalytic materials are already on the market, this technology has some drawbacks. Since toxic by-products can be formed during the photocatalytic process if contact times are not properly tuned, the undesired accumulation of toxic by-products in an enclosed environment can occur [111-113].

(iii) Photocatalytic reactors for the direct purification of industrial exhausts: photocatalytic reactors for this application have some scale-up issues and the gap between research at a laboratory scale and industrial needs is still substantial.

(iv) Giant solar photoreactors for $\mathrm{CO}_{2}$ reduction have been suggested as a possible strategy against climate change [114]: this approach has the additional benefit of producing value-added chemicals or fuels from the reduction process. However, research in this field is still in the early stages.

New applications are also emerging. In this respect, Horváth et al. [115] recently reported a photocatalytic mask filter based on $\mathrm{TiO}_{2}$ nanowires, which can be used as a protection against airborne viruses, including COVID-19, and can be photocatalytically sanitized under UV irradiation (Figure 5). Li et al. [116] fabricated a photocatalytic metal-organic framework (MOF)-based personal mask that can be self-disinfected under visible light.

(a)

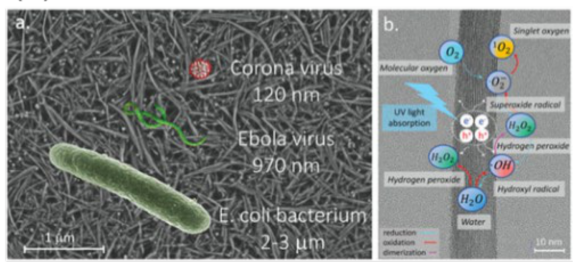

(b)
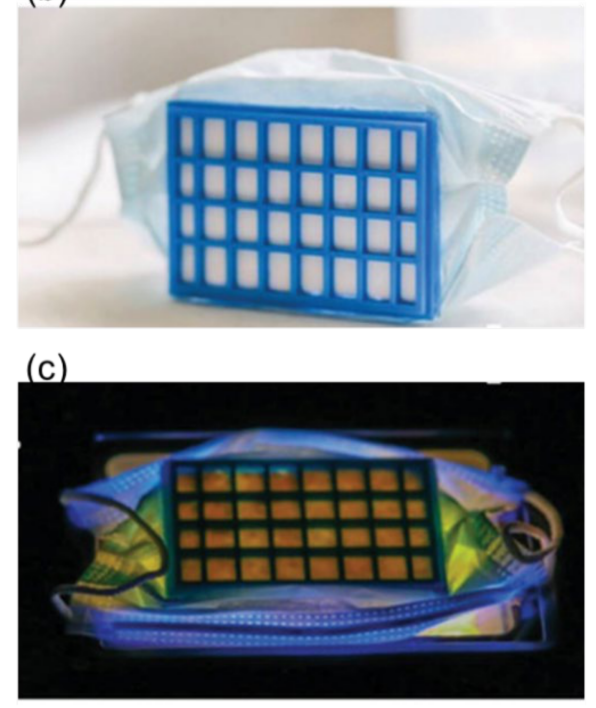

Figure 5. Photocatalytic air filters based on $\mathrm{TiO}_{2}$ nanowires, (a) photocatalytic action for the disinfection of microbial species, (b) photograph of photocatalytic mask-based filter, (c) mask disinfection under $365 \mathrm{~nm}$. Reproduced with permission from [115].

\subsection{Photocatalytic Reactors for Air Treatment}

A successful photoreactor ensures, on one hand, an excellent interaction between the gas pollutants and the immobilized photocatalyst by an enhanced surface-to-volume ratio and, on the other hand, an excellent irradiation of the photocatalyst surface [100,117-120].

Mass transfer and contact time are key parameters in photocatalytic air processing, since in air systems only adsorbed pollutants can undergo degradation by direct oxidation 
by positive holes or surface photoproduced ROS. While this issue is generally less felt in lab scale batch reactors, where contact times range from seconds to minutes [121], the design of photocatalytic reactors for treating large air volumes requires a careful optimization of mass transfer issues [122] in order to achieve a fast degradation of pollutants without the accumulation of undesired by-products. In real applications, high flow rates are needed to maximize mass transfer, but this comes at the cost of decreasing the contact time between the pollutant and the photocatalyst surface to less than $1 \mathrm{~s}$, which often results in an incomplete degradation of the pollutant. To solve this problem, different strategies have been reported, including modifications in the reactor geometry to decrease face velocity [113] or increases in the photocatalytic surface area and irradiance [117]. It should be noted that the ideal contact time depends on the adsorption affinity between the reactants and the photocatalyst/support [123].

Costa Filho et al. [117] proposed a micro-meso-structured photoreactor for the removal of gas phase n-decane by simulated solar light (Figure 6). The adopted geometry allowed a uniform irradiance of the $\mathrm{TiO}_{2}$ photocatalyst, yielding a degradation rate of $6.6 \mathrm{mmol} \cdot \mathrm{m}^{-3} \cdot \mathrm{s}^{-1}$ and no loss of activity after $72 \mathrm{~h}$ of consecutive use.
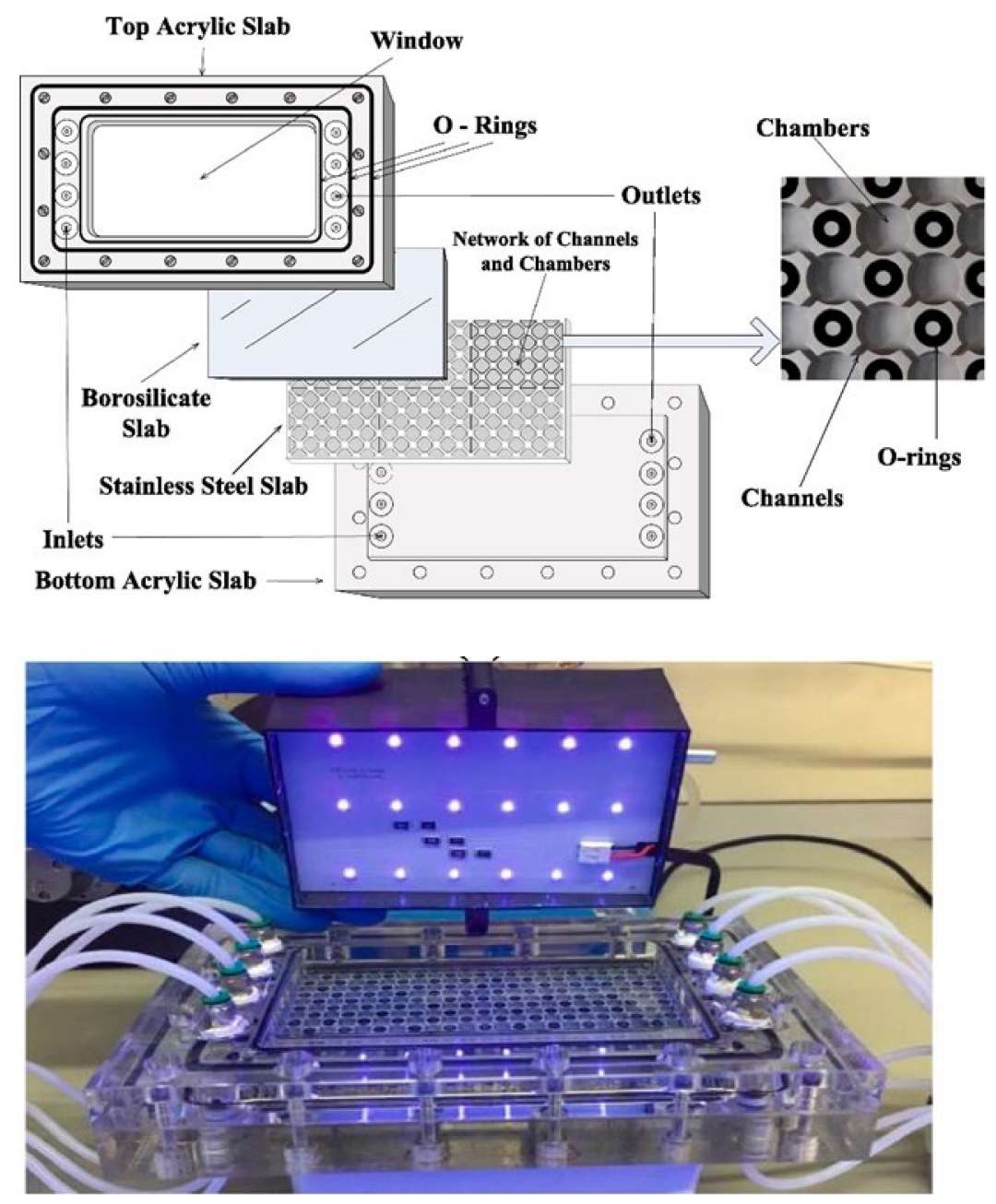

Figure 6. Schematic representation and photograph of the NETmix Microscale photoreactor with LED light for n-decane photo-oxidation in gas phase, reproduced with permission from [117], Copyright 2019, Elsevier.

Fluidized bed photoreactors have also shown a great potential for the photocatalytic purification of contaminated air. Light irradiation can be external (Figure 7e) $[124,125]$ or internal (Figure 7f) [126], and can also utilize LED lamps [123]. However, the leaching of photocatalysts from the bed was observed in this type of reactor [127]. 
Very recently, Saoud et al. reported a pilot-scale reactor for gas-phase VOC remediation and Escherichia coli inactivation based on a photocatalytic textile, based on optical fiber irradiated by UV LED [123]. A $66 \%$ degradation of $5 \mathrm{mg} \cdot \mathrm{m}^{-3}$ butane-2,3-dione was measured when the system operated at $2 \mathrm{~m}^{3} \cdot \mathrm{h}^{-1}$.

More conventional geometries adopting honeycomb monoliths have already been commercialized for the photocatalytic purification of air (Figure 7a,b). Dijk et al. [128] designed an internally illuminated honeycomb-based photoreactor for air treatment (Figure 7d) with high surface-to-volume ratio for air purification. This reactor is made for multiphase use [118], wherein the photocatalyst is coated via sol-gel in the inner walls of monolith channels. However, the drawback of this system is the need for separated illumination of each monolith channel. Transport cellulosic monoliths allow the penetration of artificial or natural solar light through all monolith channels (Figure 7c) [129-133].

(a)

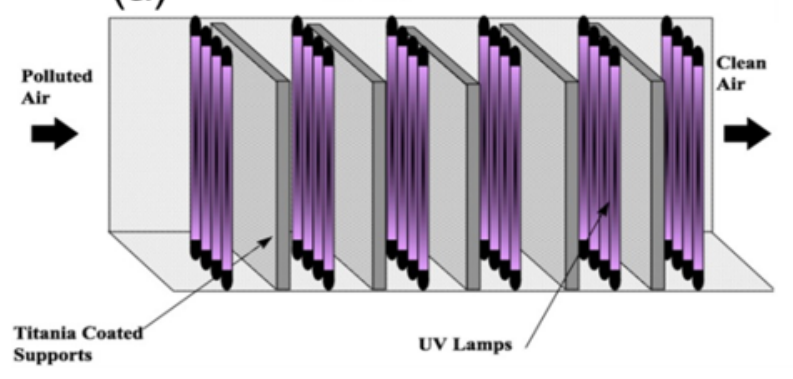

(d)

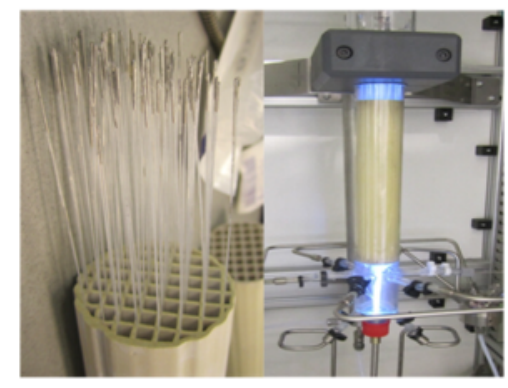

(g)

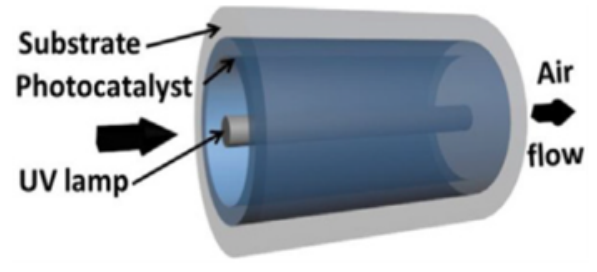

(b)



(c)

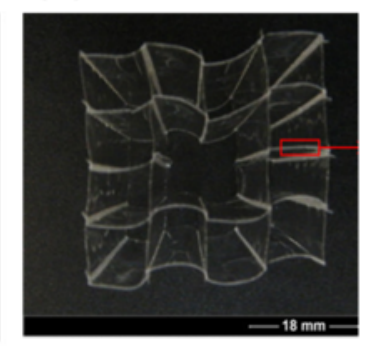

(e)

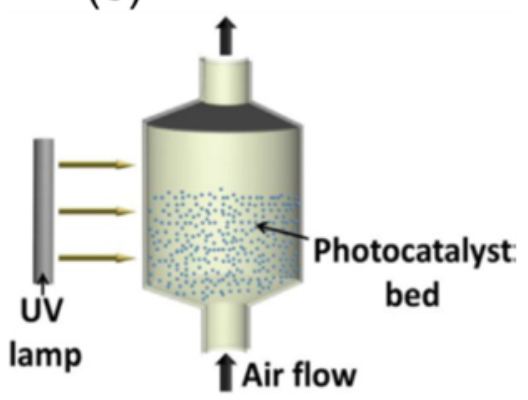

(h)

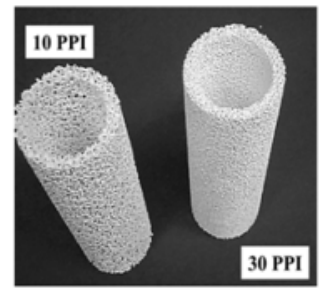

(f)

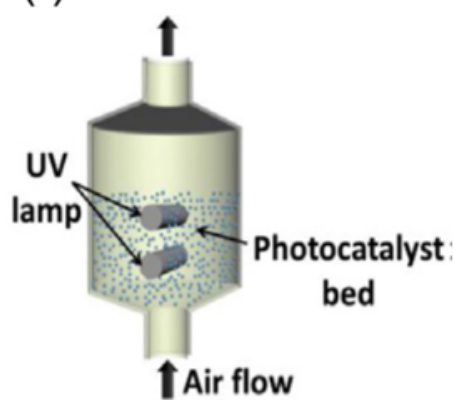

(i)

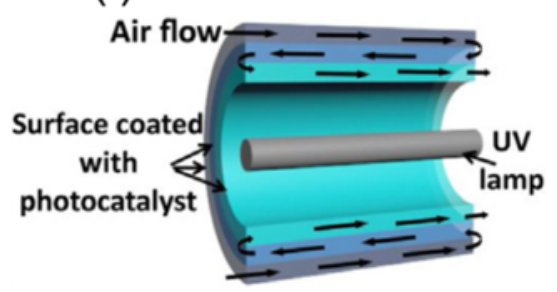

Figure 7. (a) Schematic representation of commercial-scale monolith-based reactor for air purification, reproduced with permission from reference [92]. (b) Square-channeled honeycomb monoliths, reproduced with permission from reference [130]. (c) $\mathrm{TiO}_{2}$-coated transparent monolith for air purification, reproduced with permission from reference [132]. (d) Photographs of monolith reactor equipped with light-emitting fibers inserted into the monoliths, for multiphase photocatalytic treatment, adapted with permission from [128]. (e-f) Fluidized bed photoreactor with external (e) and internal (f) irradiation, reproduced with permission from reference [127]. (g) Tubular flow photoreactor enclosing lamps with internal-wall-coated photocatalyst, reproduced with permission from reference [127]. (h) Alumina reticulated foam monoliths for the use in a photocatalytic tubular flow photoreactor, reproduced with permission from reference [130]. (i) Multi-walled tubular reactor flow photoreactor for enhanced mass transfer, reproduced with permission from reference [127]. 
Another reactor geometry for air treatment is tubular flow photoreactors enclosing lamps (Figure 7g,h) [134,135]; for enhanced mass transfer and surface-to-volume ratio, multi-wall-based reactors were constructed as shown in (Figure 7i) [136-138].

Hybrid techniques combining photocatalysis and other AOPs hold promise for the treatment of large volumes of air due to their synergistic effects. Filho et al. [139] combined $\mathrm{O}_{3} / \mathrm{UV} / \mathrm{TiO}_{2}$ for the oxidation of VOC in air streams in a NETmix micro-photoreactor system (Figure 8a). While single ozonation exhibited fast oxidation toward n-decane but very slow mineralization, the hybrid system $\mathrm{O}_{3} / \mathrm{UV} / \mathrm{TiO}_{2}$ showed a synergistic removal and mineralization. Zadi et al. [110] combined non-thermal plasma and photocatalysis for the oxidation of propionic acid and benzene in refrigerated food chambers (Figure 8b). By the use of photocatalysis as a single process, the authors reported serious gas toxicity. The combination of photocatalysis with non-thermal plasma overcomes such a toxicity issue, and on top of that, an enhanced photocatalytic efficiency was observed together with an excellent regeneration of the photocatalytic surface.

(a)

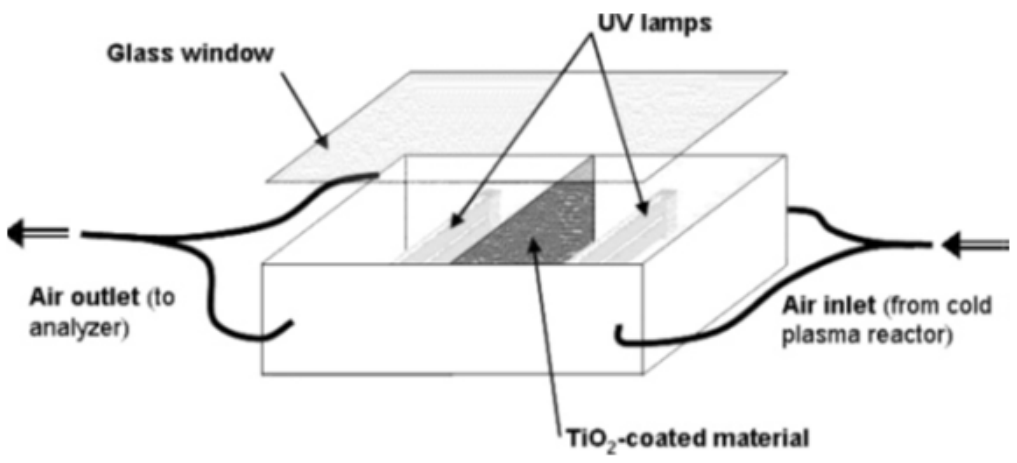

(b)

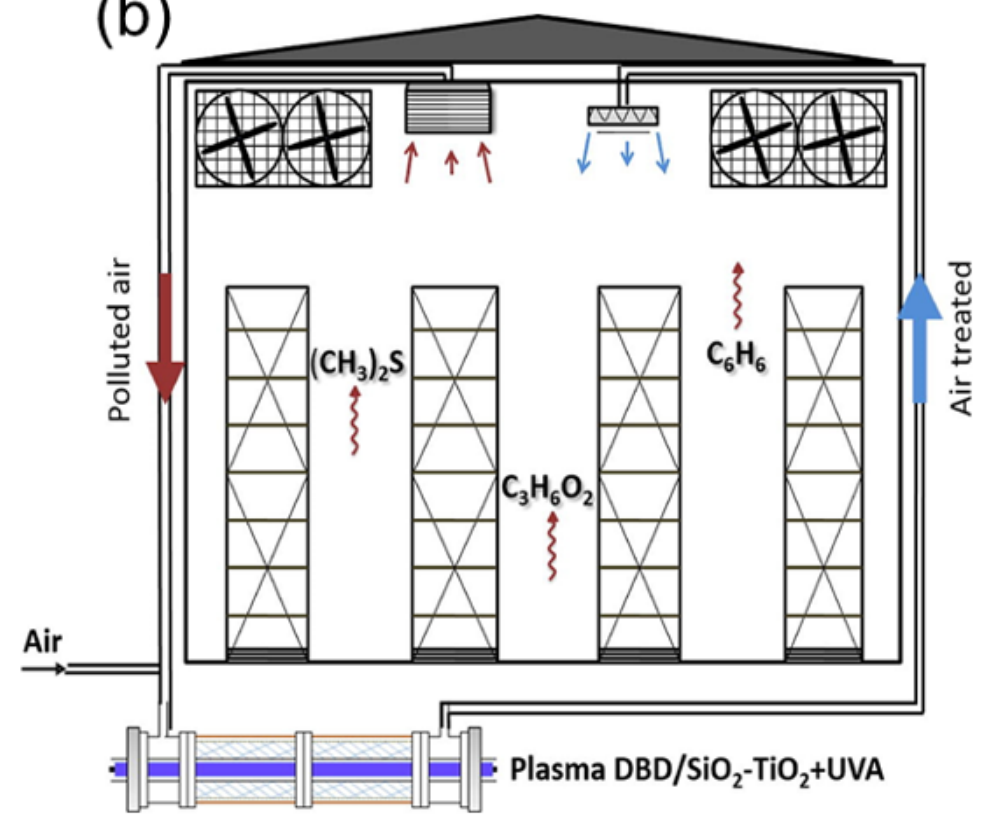

Figure 8. (a) Scheme of cold plasma and $\mathrm{TiO}_{2}$ combined system for the purification of ethanolcontaminated air, reproduced with permission from reference [140], Copyright 2007, American Chemical Society. (b) Combination of photocatalysis with non-thermal dielectric barrier discharge (DBD) plasma for the oxidation of propionic acid and benzene in refrigerated food chambers, reproduced with permission from reference [110], Copyright 2020, Elsevier. 


\subsection{Tests in Realistic Conditions}

The efficiency of air purification by photocatalysis depends on a series of operational parameters and environmental conditions. However, comparatively few studies have considered these all-important parameters in photocatalytic tests $[113,117]$ and even fewer have reported actual field tests of pilot-scale reactors [141].

First of all, the role of relative humidity should be considered. Water vapor is a ubiquitous component of air and industrial exhaust. The relative humidity of the treated effluent can vary greatly depending on the environmental conditions and process parameters, but it is generally present in concentrations far higher than those of the pollutants. Water vapor is also known to greatly affect the photocatalytic process [121]. However, there is no consensus on the effect of air humidity on the photocatalytic performance [123]. Water vapor seems to play different, conflicting roles in gas-phase photocatalysis and the overall beneficial or detrimental effect depends on parameters such as the type of pollutant and its concentration, the photocatalyst adsorption capacity and air relative humidity. It is worth mentioning that water competes for adsorption at the photocatalyst active sites, which can lead to a detrimental effect in terms of pollutant adsorption and, hence, photocatalytic activity [141]. Competition for adsorption between the reaction intermediates and water can also result in a detrimental effect in terms of mineralization [141]. On the other hand, water can react with photogenerated charges to generate reactive radicals, promoting the photocatalytic degradation. The injection of water vapor can enhance the formation of $\mathrm{HO}^{\bullet}$ species on the surface of the photocatalyst [142]. Conversely, in a dry air system, the yield of photoproduced ROS can be reduced and it is mostly related to $\mathrm{O}_{2}{ }^{-\bullet}$ species.

Air samples also contain a mixture of pollutants, generally with individual concentrations in the order of the (parts-per-billion-volume) ppbv. Most literature studies have involved photocatalytic tests with a single gas pollutant, often with concentrations in the ppm range. Higher pollutant concentrations are generally associated with improved reaction rates (until the rate reaches its plateau), poorer efficiency of removal and lower mineralization [123]. In the case of pollutant mixtures, the individual components are generally simultaneously degraded when the individual concentrations are in the ppbv range. However, the co-presence of some species, such as $\mathrm{SO}_{2}$ [141] and $\mathrm{NO}_{\mathrm{x}}$ [141], can lead to detrimental effects on the degradation of VOCs.

\subsection{Photocatalyst Deactivation}

The deactivation of photocatalyst systems is a serious issue that should be solved for a continuous processing [34]. It takes place during the photocatalytic reaction as a result of irreversible adsorption of recalcitrant by-products or site blocking by carbonaceous residues or dust particles on the surface [128]. In gas-phase photocatalysis, deactivation is a more pressing concern than it is in liquid phase, as there is no water solvent to help to remove products and intermediates from the surface.

Throughout the literature, the deactivation process has depended mainly on the characteristics of the photocatalysts, the type and concentration of pollutants. Deactivation is most severe in the presence of aromatic compounds [143,144]; however, it has been reported for a wide range of species [145]. For instance, van Dijk et al. reported photocatalyst deactivation within $80 \mathrm{~min}$ of photocatalytic operation for the oxidation of cyclohexane [128]. Despite the importance of this topic for the commercial application of photocatalytic technologies, comparatively few studies have investigated the mechanisms of deactivation, regeneration and the photocatalyst lifetime.

Several strategies to reactivate the photocatalyst have been proposed, including treatment with water vapor [128], high temperature treatment [128,145], oxidation with $\mathrm{H}_{2} \mathrm{O}_{2}$ [145] and UV irradiation [146]. The use of a more oxidizing atmosphere and better mass transfer have been reported to slow down deactivation [144]. Simple washing with water or reagents and organic solvents can be used also to regenerate the deactivated photocatalysts. Djellabi et al. reported the deactivation of $\mathrm{TiO}_{2} \mathrm{P} 25$ during the photocatalytic reduction of $\mathrm{Cr}(\mathrm{VI})$ under natural solar light [147]. It was found that $39 \%$ of reduced 
$\mathrm{Cr}(\mathrm{VI})$ was deposited as $\mathrm{Cr}(\mathrm{IIII})$ on the surface of P25, which turned the surface of P25 green. The regeneration of the P25 surface was carried out by the sequential extraction, and the leaching of $\mathrm{Cr}$ (III) was found to be $90 \%$ and $42 \%$ after three washings by citric acid and EDTA, respectively. However, the regeneration of photocatalysts at large scale is not recommended because it is time consuming and not cost effective. The use of vacuum ultraviolet or non-thermal plasma have been suggested to prevent the deactivation of photocatalysts or to enhance their lifetime. In fact, the application of the last two routes is quite hard at large scale for the treatment of large volumes. Engineering of photocatalytic materials may reduce the deactivation process. Chen et al. reported that the deactivation of $\mathrm{TiO}_{2} \mathrm{P} 25$ during the decomposition of VOCs in air phase is due to the adsorption of benzaldehyde intermediate on P25 surface, which is characterized by the high reaction energy of the aromatic ring opening [148]. The deactivation causes a dramatic decrease in VOC reduction from $72.4 \%$ to $12.3 \%$ with prolonged time. However, under the same conditions, $\beta-\mathrm{Ga}_{2} \mathrm{O}_{3}$ remains photocatalytically active along with the experiment without a decrease in the efficiency. The authors reported that $\beta-\mathrm{Ga}_{2} \mathrm{O}_{3}$ is more effective for opening the aromatic ring of intermediates, which prevents the deactivation of the photoactive surface.

Combining photocatalysis with another AOP generally promotes the lifetime of the photocatalyst. Zadi et al. [110] reported that the introduction of non-thermal plasma to the photocatalytic system can lead to continuous regeneration of the photocatalyst in air system. It was found by Ribeiro et al. [149] that addition of ozone allows the use of $\mathrm{TiO}_{2}$ without deactivation up to $77 \mathrm{~h}$.

\section{Conclusions}

Notwithstanding the myriad studies on the application of photocatalysis to air and water purification, this technology is still far from full-scale, commercial application.

To avoid concerns about the leaching into the environment of the photocatalysts and their toxicity, several attempts to design photocatalytic reactors with retained photocatalysts were presented. The designs involved the immobilization of the photocatalyst on a suitable support or in monoliths. Numerous studies have shown photocatalytic reactor designs capable of reusing the same catalyst for a few cycles with minimal loss of performance; however, more extensive tests on the photocatalyst lifetime should be performed and photocatalyst leaching should be more systematically determined.

Another critical issue is related to the adopted water matrix and the use of more realistic test conditions. Studies reporting the photocatalytic degradation of micropollutants in different water matrices (including treated municipal wastewaters, river waters, and commercial NOM) have shown that the photocatalytic activity was inhibited due to the absorption of light and scavenging of ROS by the organic backgrounds. Tests in ultra-pure water often provided indications that are not transferable to such complex systems. There is the need for a robust photocatalyst able to retain its activity in a complex water matrix and in multi-pollutant conditions.

The commercial viability and environmental sustainability of the photocatalytic technology require more attention to the determination of the costs and LCA analysis of the developed materials and processes. The application of photocatalytic remediation to municipal wastewater treatment has been so far hindered by scale-up difficulties and costs uncompetitive with conventional technologies and other AOPs. However, niche applications, such as water treatment in remote locations or the treatment of waste streams from aquaculture and hydroponics, are more promising for short-term applicability of the photocatalytic technology.

Photocatalytic air purification offers a range of applications, some already at the commercial stage. However, issues remain in terms of reactor design, especially for the treatment of large volumes of air without the emission of undesired reaction intermediates. Also, in this case, tests in more realistic conditions should be performed, including considerations about relative humidity, multi-pollutant interactions, and photocatalyst deactivation.

In general, there is the need for pilot-scale studies and tests on real samples to revamp industrial interest in the technology. 
Author Contributions: M.G.A.: Literature Survey, Writing-Original Draft; R.D.: Literature Survey, Writing-Original Draft; D.M.: Conceptualization, Writing-Original Draft; C.P.: Conceptualization, Supervision, Writing—Review \& Editing; C.L.B.: Conceptualization, Supervision, Writing-Review \& Editing, Funding acquisition; D.C.B.: Conceptualization, Project administration, Writing-Review \& Editing, Funding acquisition; All authors have read and agreed to the published version of the manuscript.

Funding: This research was funded by The Fonds de recherche du Québec-Nature et technologies (FRQNT), grant number 2021-PR-284416. The authors thank Velux Stiftung Foundation for the financial support through the project 1381 SUNFLOAT-Water decontamination by sunlight-driven floating photocatalytic systems. This research was undertaken, in part, thanks to funding from the Canada Research Chair program.

Conflicts of Interest: The authors declare no conflict of interest.

\section{References}

1. Uyguner-demirel, C.S.; Birben, N.C.; Bekbolet, M. Elucidation of background organic matter matrix effect on photocatalytic treatment of contaminants using $\mathrm{TiO}_{2}$ : A review. Catal. Today 2017, 284, 202-214. [CrossRef]

2. Bletsou, A.A.; Jeon, J.; Hollender, J.; Archontaki, E.; Thomaidis, N.S. Targeted and non-targeted liquid chromatography-mass spectrometric workflows for identification of transformation products of emerging pollutants in the aquatic environment. TrAC Trends Anal. Chem. 2015, 66, 32-44. [CrossRef]

3. Antonopoulou, M.; Kosma, C.; Albanis, T.; Konstantinou, I. An overview of homogeneous and heterogeneous photocatalysis applications for the removal of pharmaceutical compounds from real or synthetic hospital wastewaters under lab or pilot scale. Sci. Total Environ. 2021, 765, 144163. [CrossRef] [PubMed]

4. World Health Organization. World Health Statistics 2020: Monitoring Health for the SDGs, Sustainable Development Goals; World Health Organization: Geneva, Switzerland, 2020; Volume 5.

5. Richardson, S.D.; Kimura, S.Y. Water analysis: Emerging contaminants and current issues. Anal. Chem. 2019, 81, 4645-4677. [CrossRef] [PubMed]

6. Gagliano, E.; Sgroi, M.; Falciglia, P.P.; Vagliasindi, F.G.A.; Roccaro, P. Removal of poly- and perfluoroalkyl substances (PFAS) from water by adsorption: Role of PFAS chain length, effect of organic matter and challenges in adsorbent regeneration. Water Res. 2020, 171, 115381. [CrossRef] [PubMed]

7. Gar Alalm, M.; Ookawara, S.; Fukushi, D.; Sato, A.; Tawfik, A. Improved $\mathrm{WO}_{3}$ photocatalytic efficiency using $\mathrm{ZrO}_{2}$ and Ru for the degradation of carbofuran and ampicillin. J. Hazard. Mater. 2016, 302, 225-231. [CrossRef]

8. Couto, C.F.; Santos, A.V.; Amaral, M.C.S.; Lange, L.C.; de Andrade, L.H.; Foureaux, A.F.S.; Fernandes, B.S. Assessing potential of nanofiltration, reverse osmosis and membrane distillation drinking water treatment for pharmaceutically active compounds (PhACs) removal. J. Water Process Eng. 2020, 33, 101029. [CrossRef]

9. Zhang, S.; Pu, W.; Chen, A.; Xu, Y.; Wang, Y.; Yang, C.; Gong, J. Oxygen vacancies enhanced photocatalytic activity towards VOCs oxidation over Pt deposited $\mathrm{Bi}_{2} \mathrm{WO}_{6}$ under visible light. J. Hazard. Mater. 2020, 384, 121478. [CrossRef]

10. Garcia-Muñoz, P.; Fresno, F.; Lefevre, C.; Robert, D.; Keller, N. Highly robust La1-xTixFeO3 dual catalyst with combined photocatalytic and photo-CWPO activity under visible light for 4-chlorophenol removal in water. Appl. Catal. B Environ. 2020, 262, 118310. [CrossRef]

11. Loeb, S.K.; Alvarez, P.J.J.; Brame, J.A.; Cates, E.L.; Choi, W.; Crittenden, J.; Dionysiou, D.D.; Li, Q.; Li-Puma, G.; Quan, X.; et al. The technology horizon for photocatalytic water treatment: Sunrise or sunset? Environ. Sci. Technol. 2019, 53, 2937-2947. [CrossRef]

12. Serrà, A.; Philippe, L.; Perreault, F.; Garcia-Segura, S. Photocatalytic treatment of natural waters. Reality or hype? The case of cyanotoxins remediation. Water Res. 2021, 188, 116543. [CrossRef] [PubMed]

13. Hodges, B.C.; Cates, E.L.; Kim, J.H. Challenges and prospects of advanced oxidation water treatment processes using catalytic nanomaterials. Nat. Nanotechnol. 2018, 13, 642-650. [CrossRef] [PubMed]

14. Samy, M.; Ibrahim, M.G.; Fujii, M.; Diab, K.E.; Elkady, M.; Alalm, G. CNTs/MOF-808 painted plates for extended treatment of pharmaceutical and agrochemical wastewaters in a novel photocatalytic reactor. Chem. Eng. J. 2021, 406, 7. [CrossRef]

15. Adhikari, S.; Selvaraj, S.; Kim, D.H. Construction of heterojunction photoelectrode via atomic layer deposition of $\mathrm{Fe}_{2} \mathrm{O}_{3}$ on $\mathrm{Bi}_{2} \mathrm{WO}_{6}$ for highly efficient photoelectrochemical sensing and degradation of tetracycline. Appl. Catal. B Environ. 2019, 244, 11-24. [CrossRef]

16. Deng, F.; Lu, X.; Luo, Y.; Wang, J.; Che, W.; Yang, R.; Luo, X.; Luo, S.; Dionysiou, D.D. Novel visible-light-driven direct Z-scheme $\mathrm{CdS} / \mathrm{CuInS}_{2}$ nanoplates for excellent photocatalytic degradation performance and highly-efficient $\mathrm{Cr}(\mathrm{VI}) \mathrm{reduction}$. Chem. Eng. J. 2019, 361, 1451-1461. [CrossRef]

17. Xiao, H.; Zhang, W.; Yao, Q.; Huang, L.; Chen, L.; Boury, B.; Chen, Z. Zn-free MOFs like MIL-53(Al) and MIL-125(Ti) for the preparation of defect-rich, ultrafine $\mathrm{ZnO}$ nanosheets with high photocatalytic performance. Appl. Catal. B Environ. 2019, 244, 719-731. [CrossRef] 
18. Janssens, R.; Mandal, M.K.; Dubey, K.K.; Luis, P. Slurry photocatalytic membrane reactor technology for removal of pharmaceutical compounds from wastewater: Towards cytostatic drug elimination. Sci. Total Environ. 2017, 599-600, 612-626. [CrossRef]

19. Wang, Q.; Wang, P.; Xu, P.; Hu, L.; Wang, X.; Qu, J.; Zhang, G. Submerged membrane photocatalytic reactor for advanced treatment of p-nitrophenol wastewater through visible-light-driven photo-Fenton reactions. Sep. Purif. Technol. 2021, $256,117783$. [CrossRef]

20. Kumar, A.; Khan, M.; He, J.; Lo, I.M.C. Recent developments and challenges in practical application of visible-light-driven $\mathrm{TiO}_{2}$-based heterojunctions for PPCP degradation: A critical review. Water Res. 2020, 170, 115356. [CrossRef]

21. European Parliament; Council of the European Union. Regolamento (CE) n. 1223/2009 del Parlamento Europeo e Del Consiglio del 30 Novembre 2009, Sui Prodotti Cosmetici (Testo Rilevante ai Fini del SEE); Council of the European Union: Brussels, Belgium, 2009.

22. Cheng, X.; Wang, P.; Liu, H. Visible-light-driven photoelectrocatalytic degradation of diclofenac by $\mathrm{N}, \mathrm{S}-\mathrm{TiO}_{2} / \mathrm{TiO}_{2} \mathrm{NTs}_{\mathrm{photoelec}}$ trode: Performance and mechanism study. J. Environ. Chem. Eng. 2015, 3, 1713-1719. [CrossRef]

23. Parrino, F.; Corsino, S.F.; Bellardita, M.; Loddo, V.; Palmisano, L.; Torregrossa, M.; Viviani, G. Sequential biological and photocatalysis based treatments for shipboard slop purification: A pilot plant investigation. Process Saf. Environ. Prot. 2019, 125, 288-296. [CrossRef]

24. Deng, M.; Wu, X.; Zhu, A.; Zhang, Q.; Liu, Q. Well-dispersed $\mathrm{TiO}_{2}$ nanoparticles anchored on $\mathrm{Fe}_{3} \mathrm{O}_{4}$ magnetic nanosheets for efficient arsenic removal. J. Environ. Manag. 2019, 237, 63-74. [CrossRef]

25. Martín-Sómer, M.; Pablos, C.; de Diego, A.; van Grieken, R.; Encinas, Á.; Monsalvo, V.M.; Marugán, J. Novel macroporous 3D photocatalytic foams for simultaneous wastewater disinfection and removal of contaminants of emerging concern. Chem. Eng. J. 2019, 366, 449-459. [CrossRef]

26. Shephard, G.S.; Stockenström, S.; de Villiers, D.; Engelbrecht, W.J.; Wessels, G.F.S. Degradation of microcystin toxins in a falling film photocatalytic reactor with immobilized titanium dioxide catalyst. Water Res. 2002, 36, 140-146. [CrossRef]

27. Rezaei, R.; Mohseni, M. Impact of $\mathrm{pH}$ on the kinetics of photocatalytic oxidation of 2,4-dichlorophenoxy acetic acid in a fluidized bed photocatalytic reactor. Appl. Catal. B Environ. 2017, 205, 92-98. [CrossRef]

28. Khan, S.; Kim, J.; Sotto, A.; Van der Bruggen, B. Humic acid fouling in a submerged photocatalytic membrane reactor with binary $\mathrm{TiO}_{2}-\mathrm{ZrO}_{2}$ particles. J. Ind. Eng. Chem. 2015, 21,779-786. [CrossRef]

29. Rimoldi, L.; Meroni, D.; Falletta, E.; Pifferi, V.; Falciola, L.; Cappelletti, G.; Ardizzone, S. Emerging pollutant mixture mineralization by $\mathrm{TiO}_{2}$ photocatalysts. The role of the water medium. Photochem. Photobiol. Sci. 2017, 16, 60-66. [CrossRef]

30. Awfa, D.; Ateia, M.; Fujii, M.; Yoshimura, C. Photocatalytic degradation of organic micropollutants: Inhibition mechanisms by different fractions of natural organic matter. Water Res. 2020, 174, 115643. [CrossRef]

31. Ye, Y.; Bruning, H.; Liu, W.; Rijnaarts, H.; Yntema, D. Effect of dissolved natural organic matter on the photocatalytic micropollutant removal performance of $\mathrm{TiO}_{2}$ nanotube array. J. Photochem. Photobiol. A Chem. 2019, 371, 216-222. [CrossRef]

32. Martínez-Montelongo, J.H.; Medina-Ramírez, I.E.; Romo-Lozano, Y.; Zapien, J.A. Development of a sustainable photocatalytic process for air purification. Chemosphere 2020, 257, 127236. [CrossRef]

33. Garcia-Muñoz, P.; Fresno, F.; Ivanez, J.; Robert, D.; Keller, N. Activity enhancement pathways in $\mathrm{LaFeO}_{3} @ \mathrm{TiO}_{2}$ heterojunction photocatalysts for visible and solar light driven degradation of myclobutanil pesticide in water. J. Hazard. Mater. 2020, 400, 123099. [CrossRef]

34. Xu, Q.; Zhang, L.; Yu, J.; Wageh, S.; Al-Ghamdi, A.A.; Jaroniec, M. Direct Z-scheme photocatalysts: Principles, synthesis, and applications. Mater. Today 2018, 21, 1042-1063. [CrossRef]

35. Khavar, A.H.C.; Moussavi, G.; Mahjoub, A.R.; Satari, M.; Abdolmaleki, P. Synthesis and visible-light photocatalytic activity of In,S-TiO ${ }_{2} @ \mathrm{rGO}$ nanocomposite for degradation and detoxification of pesticide atrazine in water. Chem. Eng. J. $2018,345,300-311$. [CrossRef]

36. Garcia-Muñoz, P.; Fresno, F.; Lefevre, C.; Robert, D.; Keller, N. Synergy effect between photocatalysis and heterogeneous photo-Fenton catalysis on Ti-doped $\mathrm{LaFeO}_{3}$ perovskite for high efficiency light-assisted water treatment. Catal. Sci. Technol. 2020, 10, 1299-1310. [CrossRef]

37. Fang, Z.; Hu, Y.; Cheng, J.; Chen, Y. Continuous removal of trace bisphenol A from water by high efficacy $\mathrm{TiO}_{2}$ nanotube pillared graphene-based macrostructures in a photocatalytically fluidized bed. Chem. Eng. J. 2019, 372, 581-589. [CrossRef]

38. Rezaei, R.; Mohseni, M. Impact of natural organic matter on the degradation of 2, 4-dichlorophenoxy acetic acid in a fluidized bed photocatalytic reactor. Chem. Eng. J. 2017, 310, 457-463. [CrossRef]

39. Surenjan, A.; Pradeep, T.; Philip, L. Application and performance evaluation of a cost-effective vis- LED based fluidized bed reactor for the treatment of emerging contaminants. Chemosphere 2019, 228, 629-639. [CrossRef]

40. Shi, Y.; Huang, J.; Zeng, G.; Cheng, W.; Hu, J. Photocatalytic membrane in water purification: Is it stepping closer to be driven by visible light? J. Memb. Sci. 2019, 584, 364-392. [CrossRef]

41. Soliveri, G.; Sabatini, V.; Farina, H.; Ortenzi, M.A.; Meroni, D.; Colombo, A. Double side self-cleaning polymeric materials: The hydrophobic and photoactive approach. Colloids Surf. A Physicochem. Eng. Asp. 2015, 483, 285-291. [CrossRef]

42. Fischer, K.; Grimm, M.; Meyers, J.; Dietrich, C.; Gläser, R.; Schulze, A. Photoactive microfiltration membranes via directed synthesis of $\mathrm{TiO}_{2}$ nanoparticles on the polymer surface for removal of drugs from water. J. Memb. Sci. 2015, 478, 49-57. [CrossRef]

43. Lin, Y.F.; Tung, K.L.; Tzeng, Y.S.; Chen, J.H.; Chang, K.S. Rapid atmospheric plasma spray coating preparation and photocatalytic activity of macroporous titania nanocrystalline membranes. J. Memb. Sci. 2012, 389, 83-90. [CrossRef] 
44. Nunes, B.N.; Paula, L.F.; Costa, Í.A.; Machado, A.E.H.; Paterno, L.G.; Patrocinio, A.O.T. Layer-by-layer assembled photocatalysts for environmental remediation and solar energy conversion. J. Photochem. Photobiol. C Photochem. Rev. 2017, 32, 1-20. [CrossRef]

45. Hu, A.; Zhang, X.; Oakes, K.D.; Peng, P.; Zhou, Y.N.; Servos, M.R. Hydrothermal growth of free standing TiO 2 nanowire membranes for photocatalytic degradation of pharmaceuticals. J. Hazard. Mater. 2011, 189, 278-285. [CrossRef]

46. Nyamutswa, L.T.; Zhu, B.; Collins, S.F.; Navaratna, D.; Duke, M.C. Light conducting photocatalytic membrane for chemical-free fouling control in water treatment. J. Memb. Sci. 2020, 604, 118018. [CrossRef]

47. Wu, X.-Q.; Shen, J.-S.; Zhao, F.; Shao, Z.-D.; Zhong, L.-B.; Zheng, Y.-M. Flexible electrospun MWCNTs $/ \mathrm{Ag}_{3} \mathrm{PO}_{4} / \mathrm{PAN}$ ternary composite fiber membranes with enhanced photocatalytic activity and stability under visible-light irradiation. J. Mater. Sci. 2018, 53, 10147-10159. [CrossRef]

48. Liu, T.; Wang, L.; Liu, X.; Sun, C.; Lv, Y.; Miao, R.; Wang, X. Dynamic photocatalytic membrane coated with ZnIn ${ }_{2} \mathrm{~S}_{4}$ for enhanced photocatalytic performance and antifouling property. Chem. Eng. J. 2020, 379, 122379. [CrossRef]

49. Wei, Y.; Zhu, Y.; Jiang, Y. Photocatalytic self-cleaning carbon nitride nanotube intercalated reduced graphene oxide membranes for enhanced water purification. Chem. Eng. J. 2019, 356, 915-925. [CrossRef]

50. Fischer, K.; Schulz, P.; Atanasov, I.; Latif, A.A.; Thomas, I.; Kühnert, M.; Prager, A.; Griebel, J.; Schulze, A. Synthesis of high crystalline $\mathrm{TiO}_{2}$ nanoparticles on a polymer membrane to degrade pollutants from water. Catalysts 2018, 8, 376. [CrossRef]

51. Behnajady, M.A.; Modirshahla, N.; Daneshvar, N.; Rabbani, M. Photocatalytic degradation of an azo dye in a tubular continuousflow photoreactor with immobilized $\mathrm{TiO}_{2}$ on glass plates. Chem. Eng. J. 2007, 127, 167-176. [CrossRef]

52. Cerrato, G.; Bianchi, C.L.; Galli, F.; Pirola, C.; Morandi, S.; Capucci, V. Micro-TiO 2 coated glass surfaces safely abate drugs in surface water. J. Hazard. Mater. 2019, 363, 328-334. [CrossRef]

53. Abdel-Maksoud, Y.; Imam, E.; Ramadan, A. $\mathrm{TiO}_{2}$ solar photocatalytic reactor systems: Selection of reactor design for scale-up and commercialization-Analytical review. Catalysts 2016, 6, 138. [CrossRef]

54. Fouad, K.; Gar Alalm, M.; Bassyouni, M.; Saleh, M.Y. A novel photocatalytic reactor for the extended reuse of W-TiO 2 in the degradation of sulfamethazine. Chemosphere 2020, 257, 127270. [CrossRef]

55. Fouad, M.; Gar Alalm, M.; El-Etriby, H.K.; Boffito, D.C.; Ookawara, S.; Ohno, T.; Fujii, M. Visible-light-driven photocatalytic disinfection of raw surface waters (300-5000 CFU/mL) using reusable coated $\mathrm{Ru} / \mathrm{WO}_{3} / \mathrm{ZrO} 2$. J. Hazard. Mater. 2021, 402,123514 [CrossRef]

56. Samy, M.; Ibrahim, M.G.; Gar Alalm, M.; Fujii, M. MIL-53(Al)/ZnO coated plates with high photocatalytic activity for extended degradation of trimethoprim via novel photocatalytic reactor. Sep. Purif. Technol. 2020, 249, 117173. [CrossRef]

57. Samy, M.; Ibrahim, M.G.; Gar Alalm, M.; Fujii, M.; Diab, K.E.; ElKady, M. Innovative photocatalytic reactor for the degradation of chlorpyrifos using a coated composite of $\mathrm{ZrV}_{2} \mathrm{O}_{7}$ and graphene nano-platelets. Chem. Eng. J. 2020, 395, 124974. [CrossRef]

58. Stephan, B.; Ludovic, L.; Dominique, W. Modelling of a falling thin film deposited photocatalytic step reactor for water purification: Pesticide treatment. Chem. Eng. J. 2011, 169, 216-225. [CrossRef]

59. Sun, F.; He, J.; Wu, P.; Zeng, Q.; Liu, C.; Jiang, W. Magnetic photocatalyst $\mathrm{CoFe}_{2} \mathrm{O}_{4}-\mathrm{Ag}_{2} \mathrm{O}$ with magnetic aggregation bed photocatalytic reactor for continuous photodegradation of methyl orange. Chem. Eng. J. 2020, 397, 125397. [CrossRef]

60. Yu, H.; Song, L.; Hao, Y.; Lu, N.; Quan, X.; Chen, S.; Zhang, Y.; Feng, Y. Fabrication of pilot-scale photocatalytic disinfection device by installing $\mathrm{TiO}_{2}$ coated helical support into UV annular reactor for strengthening sterilization. Chem. Eng. J. 2016, 283, 1506-1513. [CrossRef]

61. Malato, S.; Blanco, J.; Vidal, A.; Fernández, P.; Cáceres, J.; Trincado, P.; Oliveira, J.C.; Vincent, M. New large solar photocatalytic plant: Set-up and preliminary results. Chemosphere 2002, 47, 235-240. [CrossRef]

62. Mueses, M.A.; Machuca-Martinez, F.; Li Puma, G. Effective quantum yield and reaction rate model for evaluation of photocatalytic degradation of water contaminants in heterogeneous pilot-scale solar photoreactors. Chem. Eng. J. 2013, 215-216, 937-947. [CrossRef]

63. Plakas, K.V.; Sarasidis, V.C.; Patsios, S.I.; Lambropoulou, D.A.; Karabelas, A.J. Novel pilot scale continuous photocatalytic membrane reactor for removal of organic micropollutants from water. Chem. Eng. J. 2016, 304, 335-343. [CrossRef]

64. Meroni, D.; Jiménez-Salcedo, M.; Falletta, E.; Bresolin, B.M.; Kait, C.F.; Boffito, D.C.; Bianchi, C.L.; Pirola, C. Sonophotocatalytic degradation of sodium diclofenac using low power ultrasound and micro sized $\mathrm{TiO}_{2}$. Ultrason. Sonochem. 2020, 67, 105123. [CrossRef] [PubMed]

65. Aoudjit, L.; Martins, P.M.; Madjene, F.; Petrovykh, D.Y.; Lanceros-Mendez, S. Photocatalytic reusable membranes for the effective degradation of tartrazine with a solar photoreactor. J. Hazard. Mater. 2018, 344, 408-416. [CrossRef]

66. Gar Alalm, M.; Samy, M.; Ookawara, S.; Ohno, T. Immobilization of S- $\mathrm{TiO}_{2}$ on reusable aluminum plates by polysiloxane for photocatalytic degradation of 2,4-dichlorophenol in water. J. Water Process Eng. 2018, 26, 329-335. [CrossRef]

67. Khaledi Maki, L.; Maleki, A.; Rezaee, R.; Daraei, H.; Yetilmezsoy, K. LED-activated immobilized Fe-Ce-N tri-doped TiO 2 nanocatalyst on glass bed for photocatalytic degradation organic dye from aqueous solutions. Environ. Technol. Innov. 2019, 15, 100411. [CrossRef]

68. Marinho, B.A.; Djellabi, R.; Cristóvão, R.O.; Loureiro, J.M.; Boaventura, R.A.R.; Dias, M.M.; Carlos, J.; Lopes, B.; Vilar, V.J.P. Intensification of heterogeneous $\mathrm{TiO}_{2}$ photocatalysis using an innovative micro-meso-structured-reactor for $\mathrm{Cr}(\mathrm{VI})$ reduction under simulated solar light. Chem. Eng. J. 2017, 318, 76-88. [CrossRef]

69. Ateia, M.; Gar Alalm, M.; Awfa, D.; Johnson, M.S.; Yoshimura, C. Modeling the degradation and disinfection of water pollutants by photocatalysts and composites: A critical review. Sci. Total Environ. 2020, 698, 134197. [CrossRef] 
70. Ren, M.; Drosos, M.; Frimmel, F.H. Inhibitory effect of NOM in photocatalysis process: Explanation and resolution. Chem. Eng. J. 2018, 334, 968-975. [CrossRef]

71. Zhao, H.; Li, G.; Tian, F.; Jia, Q.; Liu, Y.; Chen, R. g- $\mathrm{C}_{3} \mathrm{~N}_{4}$ surface-decorated $\mathrm{Bi}_{2} \mathrm{O}_{2} \mathrm{CO}_{3}$ for improved photocatalytic performance: Theoretical calculation and photodegradation of antibiotics in actual water matrix. Chem. Eng. J. 2019, 366, 468-479. [CrossRef]

72. Repousi, V.; Petala, A.; Frontistis, Z.; Antonopoulou, M.; Konstantinou, I.; Kondarides, D.I.; Mantzavinos, D. Photocatalytic degradation of bisphenol A over $\mathrm{Rh} / \mathrm{TiO}_{2}$ suspensions in different water matrices. Catal. Today 2017, 284, 59-66. [CrossRef]

73. Liu, S.; Lim, M.; Fabris, R.; Chow, C.W.K.; Drikas, M.; Korshin, G.; Amal, R. Multi-wavelength spectroscopic and chromatography study on the photocatalytic oxidation of natural organic matter. Water Res. 2010, 44, 2525-2532. [CrossRef] [PubMed]

74. Lv, J.; Han, R.; Luo, L.; Zhang, X.; Zhang, S. A novel strategy to evaluate the aromaticity degree of natural organic matter based on oxidization-induced chemiluminescence. Environ. Sci. Technol. 2020, 54, 4171-4179. [CrossRef] [PubMed]

75. Gora, S.L.; Andrews, S.A. Removal of natural organic matter and disinfection byproduct precursors from drinking water using photocatalytically regenerable nanoscale adsorbents. Chemosphere 2019, 218, 52-63. [CrossRef]

76. Drosos, M.; Ren, M.; Frimmel, F.H. The effect of $\mathrm{NOM}$ to $\mathrm{TiO}_{2}$ : Interactions and photocatalytic behavior. Appl. Catal. B Environ. 2015, 165, 328-334. [CrossRef]

77. Zhang, B.; Shan, C.; Wang, S.; Fang, Z.; Pan, B. Unveiling the transformation of dissolved organic matter during ozonation of municipal secondary effluent based on FT-ICR-MS and spectral analysis. Water Res. 2021, 188, 116484. [CrossRef]

78. Schmidt, T.C. Recent trends in water analysis triggering future monitoring of organic micropollutants. Anal. Bioanal. Chem. 2018, 410, 3933-3941. [CrossRef]

79. Schymanski, E.L.; Singer, H.P.; Slobodnik, J.; Ipolyi, I.M.; Oswald, P.; Krauss, M.; Schulze, T.; Haglund, P.; Letzel, T.; Grosse, S.; et al. Non-target screening with high-resolution mass spectrometry: Critical review using a collaborative trial on water analysis. Anal. Bioanal. Chem. 2015, 407, 6237-6255. [CrossRef]

80. Arcanjo, G.S.; Mounteer, A.H.; Bellato, C.R.; da Silva, L.M.M.; Brant Dias, S.H.; da Silva, P.R. Heterogeneous photocatalysis using $\mathrm{TiO}_{2}$ modified with hydrotalcite and iron oxide under UV-Visible irradiation for color and toxicity reduction in secondary textile mill effluent. J. Environ. Manag. 2018, 211, 154-163. [CrossRef]

81. Rueda-Marquez, J.J.; Levchuk, I.; Fernández Ibañez, P.; Sillanpää, M. A critical review on application of photocatalysis for toxicity reduction of real wastewaters. J. Clean. Prod. 2020, 258, 120694. [CrossRef]

82. Keen, O.; Bolton, J.; Litter, M.; Bircher, K.; Oppenländer, T. Standard reporting of Electrical Energy per Order (EEO) for UV/ $\mathrm{H}_{2} \mathrm{O}_{2}$ reactors (IUPAC Technical Report). Pure Appl. Chem. 2018, 90, 1487-1499. [CrossRef]

83. Benotti, M.J.; Stanford, B.D.; Wert, E.C.; Snyder, S.A. Evaluation of a photocatalytic reactor membrane pilot system for the removal of pharmaceuticals and endocrine disrupting compounds from water. Water Res. 2009, 43, 1513-1522. [CrossRef] [PubMed]

84. Miklos, D.B.; Remy, C.; Jekel, M.; Linden, K.G.; Drewes, J.E.; Hübner, U. Evaluation of advanced oxidation processes for water and wastewater treatment-A critical review. Water Res. 2018, 139, 118-131. [CrossRef] [PubMed]

85. Sadik, W.A.; El-Demerdash, A.-G.M.; Nashed, A.W.; Mostafa, A.A.; Hamad, H.A. Highly efficient photocatalytic performance of $\mathrm{Cu}_{2} \mathrm{O} @ \mathrm{TiO}_{2}$ nanocomposite: Influence of various inorganic oxidants and inorganic anions. J. Mater. Res. Technol. 2019, 8, 5405-5414. [CrossRef]

86. Mu, D.; Addy, M.; Anderson, E.; Chen, P.; Ruan, R. A life cycle assessment and economic analysis of the Scum-to-Biodiesel technology in wastewater treatment plants. Bioresour. Technol. 2016, 204, 89-97. [CrossRef]

87. Magdy, M.; Gar Alalm, M.; El-Etriby, H.K. Comparative life cycle assessment of five chemical methods for removal of phenol and its transformation products. J. Clean. Prod. 2021, 291, 125923. [CrossRef]

88. Muñoz, I.; Peral, J.; Antonio Ayllón, J.; Malato, S.; Passarinho, P.; Domènech, X. Life cycle assessment of a coupled solar photocatalytic-biological process for wastewater treatment. Water Res. 2006, 40, 3533-3540. [CrossRef]

89. Pesqueira, J.F.J.R.; Pereira, M.F.R.; Silva, A.M.T. A life cycle assessment of solar-based treatments $\left(\mathrm{H}_{2} \mathrm{O}_{2}, \mathrm{TiO}_{2}\right.$ photocatalysis, circumneutral photo-Fenton) for the removal of organic micropollutants. Sci. Total Environ. 2021, 761, 143258. [CrossRef]

90. Gar Alalm, M.; Tawfik, A.; Ookawara, S. Comparison of solar $\mathrm{TiO}_{2}$ photocatalysis and solar photo-Fenton for treatment of pesticides industry wastewater: Operational conditions, kinetics, and costs. J. Water Process Eng. 2015, 8, 55-63. [CrossRef]

91. Navarro, S.; Fenoll, J.; Vela, N.; Ruiz, E.; Navarro, G. Photocatalytic degradation of eight pesticides in leaching water by use of ZnO under natural sunlight. J. Hazard. Mater. 2009, 172, 1303-1310. [CrossRef]

92. Hay, S.O.; Obee, T.; Luo, Z.; Jiang, T.; Meng, Y.; He, J.; Murphy, S.C.; Suib, S. The viability of photocatalysis for air purification. Molecules 2015, 20, 1319-1356. [CrossRef]

93. Nath, R.K.; Zain, M.F.M.; Jamil, M. An environment-friendly solution for indoor air purification by using renewable photocatalysts in concrete: A review. Renew. Sustain. Energy Rev. 2016, 62, 1184-1194. [CrossRef]

94. Paz, Y. Photocatalytic treatment of air: From basic aspects to reactors. Adv. Chem. Eng. 2009, 36, $289-336$.

95. Peral, J.; Domènech, X.; Ollis, D.F. Heterogeneous photocatalysis for purification, decontamination and deodorization of air. J. Chem. Technol. Biotechnol. 1997, 70, 117-140. [CrossRef]

96. Demeestere, K.; Dewulf, J.; Van Langenhove, H. Heterogeneous photocatalysis as an advanced oxidation process for the abatement of chlorinated, monocyclic aromatic and sulfurous volatile organic compounds in air: State of the art. Crit. Rev. Environ. Sci. Technol. 2007, 37, 489-538. [CrossRef]

97. Escobedo, S.; de Lasa, H. Photocatalysis for air treatment processes: Current technologies and future applications for the removal of organic pollutants and viruses. Catalysts 2020, 10, 966. [CrossRef] 
98. Boyjoo, Y.; Sun, H.; Liu, J.; Pareek, V.K.; Wang, S. A review on photocatalysis for air treatment: From catalyst development to reactor design. Chem. Eng. J. 2017, 310, 537-559. [CrossRef]

99. Paz, Y. Application of $\mathrm{TiO}_{2}$ photocatalysis for air treatment: Patents' overview. Appl. Catal. B Environ. 2010, 99, 448-460. [CrossRef]

100. Birnie, M.; Riffat, S.; Gillott, M. Photocatalytic reactors: Design for effective air purification. Int. J. Low Carbon Technol. 2006, 1, 47-58. [CrossRef]

101. Costarramone, N.; Cantau, C.; Desauziers, V.; Pécheyran, C.; Pigot, T.; Lacombe, S. Photocatalytic air purifiers for indoor air: European standard and pilot room experiments. Environ. Sci. Pollut. Res. 2017, 24, 12538-12546. [CrossRef]

102. Binas, V.; Venieri, D.; Kotzias, D.; Kiriakidis, G. Modified $\mathrm{TiO}_{2}$ based photocatalysts for improved air and health quality. J. Mater. 2017, 3, 3-16.

103. De Niederhausern, S.; Bondi, M.; Bondioli, F. Self-cleaning and antibacteric ceramic tile surface. Int. J. Appl. Ceram. Technol. 2013, 10, 949-956. [CrossRef]

104. Portela, R.; Tessinari, R.F.; Suarez, S.; Rasmussen, S.B.; Hernández-Alonso, M.D.; Canela, M.C.; Avila, P.; Sánchez, B. Photocatalysis for continuous air purification in wastewater treatment plants: From lab to reality. Environ. Sci. Technol. 2012, 46, 5040-5048. [CrossRef] [PubMed]

105. Chen, J.; Poon, C. Photocatalytic construction and building materials: From fundamentals to applications. Build. Environ. 2009, 44, 1899-1906. [CrossRef]

106. Bianchi, C.L.; Pirola, C.; Stucchi, M.; Sacchi, B.; Cerrato, G.; Morandi, S.; Di Michele, A.; Carletti, A.; Capucci, V. A New Frontier of Photocatalysis Employing Micro-Sized $\mathrm{TiO}_{2}$ : Air/Water Pollution Abatement and Self-Cleaning/Antibacterial Applications; Intech Open: London, UK, 2016; ISBN 9535124846.

107. Bianchi, C.L.; Cerrato, G.; Bresolin, B.M.; Djellabi, R.; Rtimi, S. Digitally printed AgNPs doped $\mathrm{TiO}_{2}$ on commercial porcelain-grès tiles: Synergistic effects and continuous photocatalytic antibacterial activity. Surfaces 2020, 3, 11-25. [CrossRef]

108. Cerrato, G.; Galli, F.; Boffito, D.C.; Operti, L.; Bianchi, C.L. Correlation preparation parameters/activity for microTiO $_{2}$ decorated with SilverNPs for NOx photodegradation under LED light. Appl. Catal. B Environ. 2019, 253, 218-225. [CrossRef]

109. Bianchi, C.L.; Cerrato, G.; Pirola, C.; Galli, F.; Capucci, V. Photocatalytic porcelain grés large slabs digitally coated with AgNPs$\mathrm{TiO}_{2}$. Environ. Sci. Pollut. Res. 2019, 26, 36117-36123. [CrossRef]

110. Zadi, T.; Azizi, M.; Nasrallah, N.; Bouzaza, A.; Maachi, R.; Wolbert, D.; Rtimi, S.; Assadi, A.A. Indoor air treatment of refrigerated food chambers with synergetic association between cold plasma and photocatalysis: Process performance and photocatalytic poisoning. Chem. Eng. J. 2020, 382, 122951. [CrossRef]

111. Zhong, L.; Haghighat, F. Photocatalytic air cleaners and materials technologies-abilities and limitations. Build. Environ. 2015, 91, 191-203. [CrossRef]

112. Farhanian, D.; Haghighat, F.; Lee, C.-S.; Lakdawala, N. Impact of design parameters on the performance of ultraviolet photocatalytic oxidation air cleaner. Build. Environ. 2013, 66, 148-157. [CrossRef]

113. Destaillats, H.; Sleiman, M.; Sullivan, D.P.; Jacquiod, C.; Sablayrolles, J.; Molins, L. Key parameters influencing the performance of photocatalytic oxidation (PCO) air purification under realistic indoor conditions. Appl. Catal. B Environ. 2012, 128, 159-170. [CrossRef]

114. Kiesgen de_Richter, R.; Ming, T.; Caillol, S. Fighting global warming by photocatalytic reduction of CO2 using giant photocatalytic reactors. Renew. Sustain. Energy Rev. 2013, 19, 82-106. [CrossRef]

115. Horváth, E.; Rossi, L.; Mercier, C.; Lehmann, C.; Sienkiewicz, A.; Forró, L. Photocatalytic nanowires-based air filter: Towards reusable protective masks. Adv. Funct. Mater. 2020, 30, 2004615. [CrossRef] [PubMed]

116. Li, P.; Li, J.; Feng, X.; Li, J.; Hao, Y.; Zhang, J.; Wang, H.; Yin, A.; Zhou, J.; Ma, X. Metal-organic frameworks with photocatalytic bactericidal activity for integrated air cleaning. Nat. Commun. 2019, 10, 1-10. [CrossRef] [PubMed]

117. Da Costa Filho, B.M.; Araujo, A.L.P.; Padrão, S.P.; Boaventura, R.A.R.; Dias, M.M.; Lopes, J.C.B.; Vilar, V.J.P. Effect of catalyst coated surface, illumination mechanism and light source in heterogeneous $\mathrm{TiO}_{2}$ photocatalysis using a mili-photoreactor for n-decane oxidation at gas phase. Chem. Eng. J. 2019, 366, 560-568. [CrossRef]

118. Du, P.; Carneiro, J.T.; Moulijn, J.A.; Mul, G. A novel photocatalytic monolith reactor for multiphase heterogeneous photocatalysis. Appl. Catal. A Gen. 2008, 334, 119-128. [CrossRef]

119. Romero-Vargas Castrillón, S.; De Lasa, H.I. Performance evaluation of photocatalytic reactors for air purification using computational fluid dynamics (CFD). Ind. Eng. Chem. Res. 2007, 46, 5867-5880. [CrossRef]

120. Whyte, H.E. Evaluation of the Performance of Photocatalytic Systems for the Treatment of Indoor Air in Medical Environments. Ph.D. Thesis, Ecole Nationale Supérieure Mines-Télécom Atlantique, Nantes, France, 2018.

121. Lyu, J.; Zhu, L.; Burda, C. Considerations to improve adsorption and photocatalysis of low concentration air pollutants on $\mathrm{TiO}_{2}$. Catal. Today 2014, 225, 24-33. [CrossRef]

122. Thomson, C.G.; Lee, A.-L.; Vilela, F. Heterogeneous photocatalysis in flow chemical reactors. J. Org. Chem. 2020, 16, 1495-1549.

123. Mamaghani, A.H.; Haghighat, F.; Lee, C.-S. Photocatalytic oxidation technology for indoor environment air purification: The state-of-the-art. Appl. Catal. B Environ. 2017, 203, 247-269. [CrossRef]

124. Zhao, J.; Yang, X. Photocatalytic oxidation for indoor air purification: A literature review. Build. Environ. 2003, 38, 645-654. [CrossRef] 
125. Sannino, D.; Vaiano, V.; Ciambelli, P.; Eloy, P.; Gaigneaux, E.M. Avoiding the deactivation of sulphated $\mathrm{MoOx} / \mathrm{TiO} 2$ catalysts in the photocatalytic cyclohexane oxidative dehydrogenation by a fluidized bed photoreactor. Appl. Catal. A Gen. 2011, $394,71-78$. [CrossRef]

126. Cheng, Z.; Quan, X.; Xiang, J.; Huang, Y.; Xu, Y. Photocatalytic degradation of bisphenol A using an integrated system of a new gas-liquid-solid circulating fluidized bed reactor and micrometer Gd-doped $\mathrm{TiO}_{2}$ particles. J. Environ. Sci. 2012, 24, 1317-1326. [CrossRef]

127. Ren, H.; Koshy, P.; Chen, W.-F.; Qi, S.; Sorrell, C.C. Photocatalytic materials and technologies for air purification. J. Hazard. Mater. 2017, 325, 340-366. [CrossRef]

128. Van Dijk, V.H.A.; Simmelink, G.; Mul, G. The influence of water vapour on the photocatalytic oxidation of cyclohexane in an internally illuminated monolith reactor. Appl. Catal. A Gen. 2014, 470, 63-71. [CrossRef]

129. Marinho, B.A.; Cristóvão, R.O.; Djellabi, R.; Loureiro, J.M.; Boaventura, R.A.R.; Vilar, V.J.P. Photocatalytic reduction of Cr (VI) over TiO2-coated cellulose acetate monolithic structures using solar light. Appl. Catal. B Environ. 2017, 203, 18-30. [CrossRef]

130. Raupp, G.B.; Alexiadis, A.; Hossain, M.M.; Changrani, R. First-principles modeling, scaling laws and design of structured photocatalytic oxidation reactors for air purification. Catal. Today 2001, 69, 41-49. [CrossRef]

131. Monteiro, R.A.R.; Miranda, S.M.; Rodrigues-Silva, C.; Faria, J.L.; Silva, A.M.T.; Boaventura, R.A.R.; Vilar, V.J.P. Gas phase oxidation of n-decane and PCE by photocatalysis using an annular photoreactor packed with a monolithic catalytic bed coated with P25 and PC500. Appl. Catal. B Environ. 2015, 165, 306-315. [CrossRef]

132. Lopes, F.V.S.; Miranda, S.M.; Monteiro, R.A.R.; Martins, S.D.S.; Silva, A.M.T.; Faria, J.L.; Boaventura, R.A.R.; Vilar, V.J.P. Perchloroethylene gas-phase degradation over titania-coated transparent monoliths. Appl. Catal. B Environ. 2013, 140, 444-456. [CrossRef]

133. Portela, R. Eliminación Fotocatalítica de $\mathrm{H}_{2} \mathrm{~S}$ en Aire Mediante $\mathrm{TiO}_{2}$ Soportado Sobre Sustratos Transparentes en el UV-A; Universidad de Santiago de Compostela: A Coruña, Spain, 2009; ISBN 8478346104.

134. Zacarías, S.M.; Manassero, A.; Pirola, S.; Alfano, O.M.; Satuf, M.L. Design and performance evaluation of a photocatalytic reactor for indoor air disinfection. Environ. Sci. Pollut. Res. 2020, 1-9. [CrossRef]

135. Mo, J.; Zhang, Y.; Xu, Q.; Lamson, J.J.; Zhao, R. Photocatalytic purification of volatile organic compounds in indoor air: A literature review. Atmos. Environ. 2009, 43, 2229-2246. [CrossRef]

136. Imoberdorf, G.E.; Cassano, A.E.; Alfano, O.M.; Irazoqui, H.A. Modeling of a multiannular photocatalytic reactor for perchloroethylene degradation in air. AIChE J. 2006, 52, 1814-1823. [CrossRef]

137. Imoberdorf, G.E.; Cassano, A.E.; Irazoqui, H.A.; Alfano, O.M. Simulation of a multi-annular photocatalytic reactor for degradation of perchloroethylene in air: Parametric analysis of radiative energy efficiencies. Chem. Eng. Sci. 2007, 62, 1138-1154. [CrossRef]

138. Van Walsem, J.; Verbruggen, S.W.; Modde, B.; Lenaerts, S.; Denys, S. CFD investigation of a multi-tube photocatalytic reactor in non-steady-state conditions. Chem. Eng. J. 2016, 304, 808-816. [CrossRef]

139. Da Costa Filho, B.M.; Silva, G.V.; Boaventura, R.A.R.; Dias, M.M.; Lopes, J.C.B.; Vilar, V.J.P. Ozonation and ozone-enhanced photocatalysis for VOC removal from air streams: Process optimization, synergy and mechanism assessment. Sci. Total Environ. 2019, 687, 1357-1368. [CrossRef]

140. Taranto, J.; Frochot, D.; Pichat, P. Combining cold plasma and $\mathrm{TiO}_{2}$ photocatalysis to purify gaseous effluents: A preliminary study using methanol-contaminated air. Ind. Eng. Chem. Res. 2007, 46, 7611-7614. [CrossRef]

141. Maurer, D.L.; Koziel, J.A. On-farm pilot-scale testing of black ultraviolet light and photocatalytic coating for mitigation of odor, odorous VOCs, and greenhouse gases. Chemosphere 2019, 221, 778-784. [CrossRef]

142. Sun, S.; Ding, J.; Bao, J.; Gao, C.; Qi, Z.; Li, C. Photocatalytic oxidation of gaseous formaldehyde on $\mathrm{TiO}_{2}$ : An in situ DRIFTS study. Catal. Lett. 2010, 137, 239-246. [CrossRef]

143. Ardizzone, S.; Bianchi, C.L.; Cappelletti, G.; Naldoni, A.; Pirola, C. Photocatalytic degradation of toluene in the gas phase: Relationship between surface species and catalyst features. Environ. Sci. Technol. 2008, 42, 6671-6676. [CrossRef]

144. Weon, S.; Choi, $\mathrm{W}$. $\mathrm{TiO}_{2}$ nanotubes with open channels as deactivation-resistant photocatalyst for the degradation of volatile organic compounds. Environ. Sci. Technol. 2016, 50, 2556-2563. [CrossRef]

145. Walenta, C.A.; Kollmannsberger, S.L.; Kiermaier, J.; Winbauer, A.; Tschurl, M.; Heiz, U. Ethanol photocatalysis on rutile TiO 2 (110): The role of defects and water. Phys. Chem. Chem. Phys. 2015, 49, 22809-22814. [CrossRef]

146. Piera, E.; Ayllón, J.A.; Doménech, X.; Peral, J. $\mathrm{TiO}_{2}$ deactivation during gas-phase photocatalytic oxidation of ethanol. Catal. Today 2002, 76, 259-270. [CrossRef]

147. Djellabi, R.; Ghorab, F.M.; Nouacer, S.; Smara, A.; Khireddine, O. Cr(VI) photocatalytic reduction under sunlight followed by $\mathrm{Cr}(\mathrm{III})$ extraction from $\mathrm{TiO}_{2}$ surface. Mater. Lett. 2016, 176, 106-109. [CrossRef]

148. Chen, P.; Cui, W.; Wang, H.; Dong, X.; Li, J.; Sun, Y.; Zhou, Y.; Zhang, Y.; Dong, F. The importance of intermediates ring-opening in preventing photocatalyst deactivation during toluene decomposition. Appl. Catal. B Environ. 2020, 272, 118977. [CrossRef]

149. Ribeiro, B.M.B.; Fujimoto, T.M.; Bricio, B.G.M.; Doubek, U.L.R.; Tomaz, E. Gas-phase aromatic compounds degradation by a partially $\mathrm{TiO}_{2}$ coated photoreactor assisted with ozone. Process Saf. Environ. Prot. 2020, 135, 265-272. [CrossRef] 